\title{
MANUEL MARTÍ, DEÁN DE ALICANTE, ¿UN TESTIMONIO SOBRE EL FANDANGO DE COMIENZOS DEL SIGLO XVIII?
}

\author{
MANUEL MARTÍ, DEAN OF ALICANTE. A TESTIMONY ABOUT \\ THE FANDANGO OF THE EARLY $18^{\text {TH }}$ CENTURY?
}

\author{
José Francisco Ortega Castejón \\ Universidad de Murcia
}

\begin{abstract}
Resumen
Manuel Martí, deán de Alicante, describe en una carta redactada en 1712 una danza que vio bailar en Cádiz. Aunque él no lo menciona, su descripción pasa por ser el testimonio más temprano sobre el baile del fandango. Tras traducir y comentar el texto, originalmente en latín, realizamos una amplia revisión bibliográfica con el fin de explicar cómo se ha llegado a esta identificación.
\end{abstract}

Palabras clave

Fandango, calenda, chica, puellae gaditanae, deán de Alicante, libros de viaje

Una de las referencias más tempranas que, aparentemente, conservamos sobre el fandango, y a la que se recurre casi como un lugar común cuando se trata de esta variedad de danza o baile popular, es una carta escrita en latín por don Manuel Martí, deán de Alicante, fechada en Cádiz en los albores de 1712. En dicha misiva, el deán Martí describe de un modo harto gráfico el cuadro que presenció al ver ejecutar en directo "el famoso baile gaditano". Sin embargo, lo cierto es que en sus breves líneas no menciona en momento alguno el término "fandango". ¿Qué es lo que ha llevado, pues, a identificar su descripción con este baile?

Apenas recordado en la actualidad, el castellonense Manuel Martí y Zaragoza, el deán Martí, fue una de las personalidades más relevantes de la España de comienzos del

\begin{abstract}
Manuel Martí, dean of Alicante, describes in a letter written in 1712 a dance that he watched to dance in Cadiz. Though he does not mention it, his description is believed to be the earliest testimony on the fandango. After translating and commenting on the text, originally written in Latin language, we carry out a wide bibliographical review in order to explain the reason of this identification.
\end{abstract}

\section{Key Words \\ Fandango, calenda, chica, puellae gaditanae, dean of Alican- te, travel books}

XVIII, gozando como humanista y hombre de letras de un notable prestigio dentro y fuera de nuestras fronteras. Don Gregorio Mayans y Siscar (1699-1781), que profesaba hacia Martí una sincera admiración y a quien estuvo unido por una larga relación epistolar, escribió una biografía en latín que constituye la principal fuente de referencia sobre el deán ${ }^{1}$. Y, la muerte de éste, rememoró también aspectos de su vida y de su especial carácter en una carta dirigida a Don Francisco de Almeida, miembro de la Real Academia de la Historia Portuguesa, en la que le comunicaba la luc-

1 MAYANS (1735). 
tuosa noticia del deceso de Martí ${ }^{2}$. Cabe destacar que ya en 1749 Antonio Ximeno dedica una entrada al deán, basada principalmente en la biografía de Mayans, en su diccionario de autores valencianos ${ }^{3}$. Más recientemente, el profesor Luis Gil, traductor de la biografía realizada por don Gregorio ${ }^{4}$, ha aportado nueva luz sobre Martí, al haber tenido la fortuna de dar en la Biblioteca Municipal de Valencia con los apuntes autobiográficos que el propio deán suministró a su biógrafo 5 . Por su parte, el profesor Antonio Mestre, especialista en la obra de Mayans, también ha dedicado algunos de sus trabajos a glosar la figura de Martí, principalmente por la relación que unió a ambos humanistas ${ }^{6}$. A todos ellos, por tanto, remitimos a quien desee profundizar más sobre este singular personaje, de cuya vida ofreceremos tan sólo unas breves pinceladas?

Manuel Martí y Zaragoza nace en Oropesa del Mar (Castellón) el 19.07.1663, mostrando pronto una clara inclinación por el campo de las letras y las humanidades. En 1686 marcha a Roma a fin de completar su formación, estancia que se prolonga hasta 1696. Allí trabaja como bibliotecario para el cardenal Sáenz de Aguirre (1630-1699), participando en la preparación de las ediciones de la Collectio maxima conciliorum Hispaniae (Roma, 1694), iniciativa del propio prelado, y de la Bibliotheca hispana vetus (Roma, 1696) del célebre Nicolás Antonio (1617-1684). A su retorno a España, fija su residencia en Alicante pues trae consigo la dignidad eclesiástica de deán de la Colegiata de San Nicolás. Sin embargo, la poca actividad intelectual que aquí encuentra lo lleva a abandonar pronto la ciudad portuaria, asentándose durante un tiempo en Valencia y, más tarde, a partir de 1704, en Madrid, donde entra al servicio como bibliotecario del Duque de Medinaceli. La caída en desgracia de éste, que termina con su prisión y precipitada muerte, así como las afecciones que el propio deán padece, lo conducen a Sevilla, donde permanece desde finales de 1710 hasta 1715 . Vuelve de nuevo a Madrid pero, hastiado de la indiferencia y la falta de reconocimiento con la que se le trata, regresa a Alicante. No por mucho tiempo, ya que en 1717 embarca camino a Roma, la ciudad de sus an-

2 MAYANS (1773): II, 382-397. Francisco de Almeida, arcediano de San Pedro de France y académico de la Real Academia de la Historia portuguesa, ordenó celebrar en memoria de Martí unas exequias fúnebres en Lisboa, en el transcurso de las cuales el catedrático de letras humanas Antonio Felix Mendes recitó una Oratio in Obitum Maximi Hispanorum D. D. Emmanuelis Martini Decani Alonensis.

3 XIMENO (1774): II, 250-256.

4 GIL (1977).

5 GIL (1978): 47-101; y GIL (1984): 265-314.

6 MESTRE (1980): 14-57; y MESTRE (2003).

7 Sobre las obras de Manuel Martí así como los estudios a él dedicados hasta la fecha de edición de la obra, $c f$. DÍAZ (1995): vol. V. helos. Aunque de nuevo el infortunio, materializado en un edicto de Felipe V por el que ordena abandonar la Ciudad Eterna a todos los españoles, da al traste con la intención que tiene de fijar allí su residencia. Se ve obligado, por tanto, a retornar a Alicante a finales de 1718; vuelta que será ya definitiva, pues allí seguirá hasta su muerte, acaecida el 21.04.1737.

Martí fue un hombre de carácter difícil y poco amigo de circunloquios cuando de decir la verdad se trataba; de ahí que se granjeara una fama no demasiado favorable para él. Según Mayans, "El Deán decía y escribía lo que sentía y, como su lenguaje era el de la verdad, se hacía odioso a muchos" ${ }^{\text {. }}$. De forma que se fue encerrando cada vez más en sí mismo, aislándose de una sociedad que no lo valoraba lo suficiente. Sus últimos años hubieran sido de un gris aplastante de no haberse cruzado en su camino don Gregorio Mayans. Efectivamente, el 02.12.1720 Mayans envió a Martí la primera carta de lo que se convertiría con el tiempo en una densa relación epistolar que se prolongó hasta el final de los días del deán ${ }^{9}$. Esta casi frenética actividad evitó a buen seguro que la melancolía que asolaba a Martí, derivada de la indiferencia con la que sentía ser tratado en su propio país, se tradujera en un desánimo total. En la epístola a Francisco de Almeida, lamenta Mayans las dificultades que en España tienen por sobresalir hombres como Martí, de quien, no duda, la posteridad hará justicia:

[...] los ingenios Españoles son como las minas de plata y oro que hay en España: muy preciosos, pero muy ocultos. Está hoy Europa llena de la fama de don Manuel Martí. Admiróle Roma aun en el oriente de su saber, y allí logró el deanazgo, dignidad muy corta con que no pudo lucirse. Pero España para él fue el lugar de su ocaso, y Alicante, el sepulcro de su fama. La posteridad, que siempre hace justicia, no le negará la gloria que se mereció $[\ldots]^{10}$

Fue el propio Mayans, sabedor de la valía intelectual del deán así como de su atinado juicio en temas relativos a la Antigüedad Clásica, quien más hizo al respecto al fijarse el propósito de publicar sus obras: lamentablemente sólo aquellas que lograron salvarse de los afanes destructivos que de cuando en cuando asaltaban a Martí. Sea como fuere, pudo dar a la imprenta parte de la correspondencia que mantuvo

8 MAYANS (1773): 383-384.

9 Cf. MAYANS (1773): 383 "Desde el año veinte, en que empecé a tratarle por escrito [...]".

10 MAYANS (1773): 387. 
con diversas personalidades de la época, incorporando además la biografía antes mencionada, en la que Mayans describe de forma minuciosa la trayectoria vital del deán.

Divididos en dos volúmenes, los Epistolarum libri duodecim vieron la luz, divididos en dos volúmenes, en Madrid en 1735: una edición que, al menos fuera de España, pasó prácticamente desapercibida ${ }^{11}$. Sin embargo, las buenas relaciones que Gregorio Mayans mantenía con diferentes personalidades europeas $y$, especialmente, con el embajador británico Benjamin Keene, posibilitaron que la obra de Martí se reeditara en Amsterdam en $1738^{12}$. Keene, que se había hecho cargo de los costes de la edición madrileña, recibió del humanista holandés Wesselingio el proyecto de publicación, encargándose Mayans de preparar las adiciones, entre otras el texto del Pro crepitu ventris que, localizado tras la muerte del deán, se incorporó a la edición holandesa ${ }^{13}$. Aunque ya tarde para Martí, que no pudo ver cumplidas en vida sus ansias de reconocimiento, esta edición supuso la difusión europea de su obra. Un dato muy a tener en cuenta para nosotros, pues la carta objeto de este trabajo será repetidamente citada a partir de entonces por diferentes autores de los siglos XVIII y XIX, principalmente en libros de viaje por España; y también lo ha seguido siendo, aunque ya de un modo indirecto, en la actualidad.

Los epistolarios constituyen, qué duda cabe, una fuente de conocimientos de primer orden, un instrumento válido para familiarizarse con la vida cotidiana y social de una época ${ }^{14}$. Los autores aportan en sus cartas datos y noticias esenciales sobre diversos temas, ya sean de naturaleza histórica, científica o literaria, aunque sólo sea para exponer su opinión sobre ellos. Naturalmente, habrá que tener presente la subjetividad del autor, por lo que, en la medida de lo posible, será conveniente contrastar la información con lo que aporten otras fuentes.

La carta del deán de nuestro interés pertenece al libro VII de las epístolas martinianas. Se trata, en concreto, de la carta $\mathrm{n}^{\circ} 7$, incluida en el segundo volumen de la obra, páginas 12-14 en la edición madrileña y 7-8, en la holandesa. De ella reproducimos el texto en original en latín, al que seguirá nuestra traducción al castellano.

11 MARTÍ (1735).

12 MESTRE (2007), 16

13 MARTÍ (1738). El Pro crepitu ventris es una obra de juventud de Martí, en la que diserta en un latín muy ingenioso sobre un tema harto frívolo como el de las ventosidades. Roque Valero la tradujo al castellano a finales del XVIII con el título Oración que en defensa del pedo compuso el doctísimo y célebre don Manuel Martí (Sevilla, Imprenta de Vázquez, Hidalgo y Compañía, s.f.).

14 MESTRE (2000): 13-26.
Emmanuel Martinus Joachimo Alcarazio, ornatissimo juveni

S. D.

Mantuam Carpetanorum

I nunc et veterum morum licentiam accusa, nostrorum verecundia lauda. Nosti saltationem illam gaditanam, obscoenitate sua per omne aevum famosam. Atqui hodie ipsammet per omnia huius urbis compita, per omnia cubicula, cum incredibili adstantium plausu saltari videas. Nec inter Aethiopas tantum et obscuros homines, sed inter honestissimas feminas ac nobili loco natas.

Saltationis modus hoc ritu peragitur. Saltant vir et femina, vel bini, vel plures. Corpora ad musicos modos per omnia libidinum irritamenta versantur. Membrorum in ea mollissimi flexus, clunium motationes, micationes femorum, salacium insultuum imagines. Omnia denique turgentis lasciviae solertissimo studio expressa simulacra. Videas cevere virum et, cum quodam gannito, crissare feminam, eo lepore ac venustate ut ineptae profecto ac rusticae tibi viderentur tremulae nates Photidos appulejanae. Denique, talem peragunt saltationem qualem verisimile est suum Herculem cum Omphale saltasse.

Interea omnia constrepunt cachinnis et ronchis. Quin

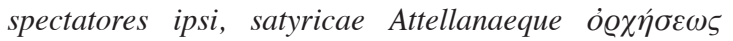
furore correpti, in ipso simulatae libidinis campo, leni quodam gestu nutuque velitantur ac fluctuant.

En gaditanas delicias, prae quibus phrygiam illam xó $\delta \alpha \varkappa \alpha$ quid aliud existimabis praeter meras nugas?

Quod ad urbem spectat, habes, me-hercules, emporium utriusque orbis commercio et opibus florentissimum, ingenioque loci situque peropportunum.

Nihilne (dices) de Letheo flumine? De Elysiis? Illud quidem trajeci, nec tui oblitus sum. In his versor, nec ideo me beatum iudico nisi te denuo amplectar, cuius desiderio contabesco.

Vale iterum atque iterum.

Ex Herculis stelis et extremo mundo, Gadibus, XVI Kal. Februarias, MDCCXII.

De reditu nostro ad vos, nihildum certi. Cras ad Menesthei Portum trajicere paro, inde Hispalim me conferam. Vale

Manuel Martín envía un saludo al distinguidísimo joven Joaquín de Alcaraz 
A Mantua de los Carpetanos ${ }^{15}$

¡Ve tú ahora y censura el libertinaje de las viejas costumbres, alaba el recato de las nuestras! Has oído hablar de la danza gaditana, famosa de toda la vida por su procacidad. Pues bien, podrías comprobar que a día de hoy se baila en todas las plazas públicas, en todos los rincones de esta ciudad, y con el increíble asentimiento de los presentes.

La forma de bailarla, y no sólo entre los etíopes ${ }^{16}$ y personas de más baja condición social, sino también entre las mujeres de más ilustre linaje y nacidas de noble cuna, se ejecuta de la manera que expongo. Bailan un hombre y una mujer, bien una sola pareja, o bien más de una. Al compás de la música, los cuerpos se mueven reflejando todo lo que aviva el deseo; con este propósito, las suavísimas ondulaciones de los miembros, el bamboleo de las nalgas, el batimiento ${ }^{17}$ de los muslos, los simulacros de obscenas embestidas; en definitiva, representación todo de una no disimulada lascivia, expresada con celosísimo entusiasmo. Verías al hombre traquetear su trasero y, con un verdadero gemido, a la mujer menear el suyo; con tanta gracia y donaire que las trémulas nalgas de la Fotis apuleyana ${ }^{18}$ te parecerían desmañadas y zafias. En fin, que ejecutan la danza tal y como es muy probable que Hércules bailara la suya con Onfalia ${ }^{19}$.

Mientras, hacen resonar todo con risas y burlas. Es más, los propios espectadores, llevados por el furor de

15 Nombre con el que, se supone, se denominó en otro tiempo el enclave que ocupa Madrid.

16 El gentilicio "aethiops" se emplea para designar de modo genérico a las gentes de piel negra, por lo que, en un principio, nos inclinaríamos a pensar que lo que aquí describe Martí es un baile de origen negro. No obstante, hay quien afirma que a los gitanos, además de por "egipcios", se les conocía también por "etíopes" o, incluso, por "ethigitanos", que es como aún los denomina en 1809 el arabista José Antonio Conde, el primer compilador del dialecto gitano en España; $c f$. TORRIONE (1992): 9-30.

17 Algunos diccionarios latinos traducen el sustantivo verbal "micatio" por "patada" o "coz". El verbo "micare", del que deriva, indica un rápido movimiento, y su equivalencia en castellano es "agitarse, temblar, palpitar, batir" y verbos similares. En todo caso, no creemos oportuno traducir "micationes femorum", como hace Ruiz Campos, por "taconeos", pues consideramos que de haber querido expresar eso, Martí hubiera empleado el genitivo de "talus" o "calx" (ambos sustantivos pueden traducirse por "talón") o el de "pes" ("pie"). $C f$. RUIZ CAMPOS (2002): vol. I, 294.

18 Fotis es el nombre de una hermosa muchacha por la que se siente atraído el protagonista de El asno de oro, del escritor latino Apuleyo. Remitimos especialmente al capítulo II 7, donde se describe una sensual escena, que es la que posiblemente rememora Martí.

19 Referencia a los amores carnales del mítico Hércules con Ónfale u Onfalia, reina de Lidia, a quien tuvo que servir como esclavo para expiar sus culpas. Tema reproducido de forma recurrente en la pintura, los artistas acostumbran a presentar a ambos personajes desnudos, en escenas cargadas de sensualidad. esta danza satírica y atelana ${ }^{20}$, en un mismo escenario de fingido desenfreno, caracolean y se mecen con ademanes verdaderamente lánguidos y asintiendo con la cabeza.

He aquí las delicias de los gaditanos, a la vista de las cuales ¿qué otra cosa que una mera bagatela cabe considerar la cordax frigia ${ }^{21}$ ?

En lo que atañe a la ciudad ${ }^{22}$, tienes, a fe mía, una plaza comercial muy próspera por el tráfico y las riquezas de una y otra parte del mundo; y muy adecuada por las condiciones del lugar y su emplazamiento.

¿Y no hay nada (te preguntarás) del río Leteo ni de los Campos Elíseos ${ }^{23}$ ? Aquel, sin duda, lo atravesé; y no me he olvidado de ti. En cuanto a los segundos, en ellos me encuentro, y no por eso me considero afortunado; a no ser que te abrace de nuevo, cuyo anhelo me consume.

Adiós y adiós.

Desde las Columnas de Hércules y los confines del mundo ${ }^{24}$, en Cádiz, a 17 de Enero de 1712.

De mi regreso junto a vosotros, nada hay cierto. Me preparo para trasladarme mañana al Puerto de Menesteo $^{25}$, desde donde me dirigiré a Híspalis ${ }^{26}$.

Adiós.

Atendiendo a la norma del calendario romano, la carta está fechada el 17.01.1712 27. Martí la dirige a un tal Joaquín de Alcaraz, un joven con pretensiones literarias que se acercó a Martí buscando su asesoramiento; una

$20 \mathrm{La}$ atelana era una pieza cómica de los latinos, de carácter ridículo y picante.

21 Danza de la Antigüedad Clásica, de carácter lascivo e indecente.

22 Se refiere, naturalmente, a la ciudad de Cádiz.

23 Los Campos Elíseos es la morada a la que van los héroes y los hombres virtuosos después de su muerte, que previamente han de beber las aguas del río Leteo para olvidar su anterior vida. Aunque Martí parece aludir aquí a las circunstancias personales que lo llevaron a abandonar Madrid y asentarse por un tiempo en Andalucía. No hay que descartar, sin embargo, algún guiño a la historia, pues en el Puerto de Santa María desemboca el río Guadalete, el "río del olvido", denominado así en conmemoración de una batalla que no llegó a celebrarse entre griegos y fenicios. A este respecto, existía una leyenda que situaba los Campos Elíseos en Cádiz, pues para llegar allí había que cruzar el río Lete o Leteo, que cambió su nombre por el de Guadalete; $c f$. LABAT (1731): vol. I, 47-49.

24 Los antiguos griegos dieron el nombre de Columnas de Hércules a los dos altos promontorios que, a uno y otro lado de la costa, flanquean la entrada oriental del Estrecho de Gibraltar, que señalaba el límite del mundo conocido.

25 El Puerto de Santa María, en Cádiz.

26 Sevilla.

27 La fecha "XVI Kal. Februarias" ha de entenderse como "ante diem (a. d.) XVI Kalendas Februarias", es decir, dieciséis días antes de las calendas (día primero del mes para los romanos) de Febrero; por tanto, 17 de Enero. Como veremos después, hay quienes la fechan bien el 16 de Febrero, o bien el 17 de Marzo. 
relación que prometía pero que no acabó precisamente bien $^{28}$.

En lo que atañe al contenido de la carta, hay algunos aspectos que nos interesaría poner de relieve, pues creemos que son fundamentales para entender el "punto de vista" de Martí cuando describe la "danza gaditana".

La muerte de su protector, el duque de Medinaceli, así como su propia salud, algo quebrantada, impulsaron a Martí a abandonar Madrid en el verano de 1710 y dirigirse a tierras andaluzas en busca de un clima más propicio. Nuestro deán era un enamorado y estudioso de la Antigüedad Clásica por lo que, siempre que pasaba por algún lugar de importancia histórica, aprovechaba la ocasión para realizar algún descubrimiento o recopilar datos y materiales de otras épocas; principalmente monedas y medallas, de las que logró reunir una gran colección. Así lo manifiesta el propio deán en los apuntes autobiográficos que redactó para Mayans:

... partió para Sevilla en el año de diez a últimos de agosto, con poca salud, la cual empezó a recobrar con lo benigno de aquel clima. Y encontrándose con más aliento, emprendió con nuevo fervor la pesquisa y conquista de medallas, manuscritos antiguos y otras antiguallas, habiendo ejecutado esta misma diligencia en el viaje. En todos los lugares donde paraba, sus diligencias eran tomar lengua y noticia sobre ese asunto, frecuentar muy a menudo los plateros y latoneros y caldereros, que es a donde van a parar en España semejantes tesoros; escribir cartas a los lugares de aquel contorno, $\mathrm{y}$ valerse de amigos para que le ayudaran. Y fue con tan feliz suceso, que, en cuatro años y diez meses que residió en aquella ciudad, recogió mil y seiscientas medallas distintas ${ }^{29}$.

Y también incide en este aspecto la biografía mayansiana:

En el año 12 del siglo en curso, el 4 de enero se fue de Sevilla al Puerto de Santa María. La mitad del camino la hizo arrecido por una helada rigurosísima, el resto con cielo lluvioso; sin embargo, llegó al Puerto sin incidencias el día 6 de dicho mes. Pasó allí el verano y evitó muy confortablemente la molestia del calor en casa de un amigo flamenco. Arrampló cuantas viejas monedas pudo a costa de gastar las nuevas. De allí se dirigió a

28 Martí cuenta a Mayans, en una carta fechada el 30.08.1721, las razones de tal desavenencia, que parece derivarse del enfado del joven ante la crítica poco favorable con la que Martí recibió una composición suya. La carta, editada por Mestre, puede leerse en edición electrónica en la Biblioteca Digital Valenciana; consultada el 05-10-2011 en http://bv2.gva.es/es/corpus/unidad.cmd?idCorpus=20000\&idUnida $\mathrm{d}=48616$ \&posicion $=1$.

29 GIL (1984): 296.
Cádiz, donde encontró muchas más y éstas, fenicias, que allí se encuentran fácilmente, ya que fueron fenicios los fundadores de Cádiz. Volvió después sobre sus pasos y regresó a Sevilla con la salud restablecida ya y más alegre el ánimo ${ }^{30}$.

La imagen de Martí que transmiten estos textos es clave para nosotros, pues estamos convencidos de que su visión de la danza que vio bailar en Cádiz está mediatizada por la erudición y el conocimiento que tenía del mundo clásico. Creemos, en concreto, que está influenciada por el recuerdo de las famosas puellae gaditanae, y la razón principal radica en el vocabulario que emplea.

Éste nos remite de forma inequívoca a las descripciones clásicas del baile de estas muchachitas gaditanas transmitidas, entre otros, por las obras de Marcial y Juvenal, y también por los denominados Carmina Priapea, una colección de poemitas dedicados a la figura del dios Príapo. Hay que tener presente que Martí era todo un especialista en Marcial, de quien tradujo, nada menos que al griego clásico, algunos de sus dísticos más obscenos ${ }^{31}$.

En la Roma clásica, el baile de las puellae gaditanae, que gozaban de una dudosa reputación, causaba sensación y espanto a partes iguales. Marcial, el poeta de la antigua Bílbilis (hoy Calatayud), rememora en uno de sus epigramas los lascivos movimientos de estas jovencitas. Destacaremos en negrita algunos de los términos que emplea:

\section{[...] nec de Gadibus improbis puellae vibrabunt sine fine prurientes \\ lascivos docili tremore lumbos $[\ldots]^{32}$}

También Juvenal se fija en los meneos de estas jóvenes que, cual infalible afrodisiaco, a nadie dejan indiferente:

Forsitan expectes ut Gaditana canoro incipiant prurire choro plausuque probatae ad terram tremulo descendant clune puellae. Spectant hoc nuptae iuxta recubante marito, quod pudeat narrare aliquem praesentibus ipsis.

Irritamentum veneris languentis et acres divitis urticae $[\ldots]^{33}$

30 GIL (1977): 159.

31 Cf. GIL (1991): 29-42.

32 MARCIAL: Epigramas, V 78, 26: "Ni las jovencitas de la impúdica Gades sacudirán, en un paroxismo sin límite, sus lascivos lomos con vivo temblor".

33 JUVENAL: Sátiras, XI 162-168: "Tal vez esperes que las melodías gaditanas comiencen a crear excitación con su sonoro séquito y que, animadas por los aplausos, las muchachas desciendan hasta el suelo con su culo tembloroso. Esto, que a cualquiera daría vergüenza 
Un espectáculo al que no podría sustraerse ni el mismísimo Hipólito, hijo de Teseo y Antíope, encarnación de la castidad a ultranza y que supo salir airoso de las incitaciones de su madrastra Fedra:

Tam tremulum crisat, tam blandum prurit, ut ipsum masturbatorem fecerit Hippolytum ${ }^{34}$.

Los Carmina Priapea inciden de nuevo en esta hipérbole al referir la irresistible sensualidad del baile gaditano, de cuyo influjo no se libraría ni el propio hijastro de Fedra, es decir, Hipólito:

Hic quando Telethusa circulatrix, quae clunem tunica tegente nulla extans altius altiusque motat, crissabit tibi fluctuante lumbo:

haec sic non modo te, Priape, posset, privignum quoque sed movere Phaedrae ${ }^{35}$.

Basta comparar estas citas con el cuadro que describe Martí para caer en la cuenta de qué y a quién tenía en mente nuestro deán cuando pinta esos meneos de nalgas y caderas, esa representación, apenas disimulada, del acto sexual. De hecho, la práctica totalidad del vocabulario que emplea en el párrafo cumbre de su carta, el más escabroso, tiene connotaciones sexuales, y como tal aparece recogido, por poner un caso, en el Thesaurus eroticus linguae latinae de Karl Rambach (Stuttgart, 1833). No conocemos el nivel de latín que tendría el jovencito Joaquín de Alcaraz pero, aunque fuera con la ayuda de un diccionario, nos atreveríamos a decir que la epístola de Martí cuando menos turbó su espíritu.

El caso es que esta misiva del deán de Alicante ha devenido en tópico de obligada referencia cuando del fandango se trata, dándose por hecho que es uno de los primeros testimonios que se tienen de este popular baile. Algunos autores mencionan tan sólo su existencia, pero los hay también que incluyen fragmentos más o menos extensos de la misma, bien en versión original o, sobre todo entre los recientes, traducidos a lenguas modernas. Se observa, no obstante, que la

contarlo delante de ellas, lo contemplan las casadas junto a sus maridos recostados. Es un estímulo para el deseo que languidece y un picante aguijonazo para el rico".

34 MARCIAL: Epigramas, XIV 203: "Con tales sacudidas se menea, tan seductoramente se apasiona, que hasta del propio Hipólito haría un onanista".

35 CARMINA PRIAPEA XIX: "Si un día Teletusa, la pindonga, que mueve su culo sin cubrirse con túnica alguna mostrándose más y más alto, se menea para ti meciendo sus lomos, esa podría excitarte no sólo a ti, Priapo, sino al mismísimo hijastro de Fedra". mayoría de los que la citan lo hacen de modo indirecto, esto es, recogiendo la referencia (y, en ocasiones, el texto original o la traducción), de una fuente anterior, sin cuestionarse de ordinario si el deán Martí realmente describía o no en ella el fandango. Interesados en analizar cómo esta referencia se ha ido transmitiendo de época en época, nos propusimos seguir su pista, lo que nos ha permitido vislumbrar una cadena de transmisión apenas interrumpida hasta el presente en la que destacan tres eslabones fundamentales: Jean François Peyron y Charles Davillier, ambos afamados autores de libros de viaje y, ya más cercano a nosotros, Aurelio Capmany.

Las fuentes literarias tienen un notable valor para el estudioso pues, directa o indirectamente, describen usos y costumbres, permitiéndonos conocer, por ejemplo, el folclore musical de una época ${ }^{36}$. Tienen, sin embargo, una naturaleza frágil, ya que acostumbran a expresar opiniones relativas y parciales de la realidad; aunque, por otra parte, siguen siendo válidas como reflejo de una parte de esa misma realidad ${ }^{37}$.

La literatura de viaje constituye todo un boom de ventas en los siglos XVIII y XIX, convirtiendo a España en uno de los destinos preferentes. El viajero europeo inicia frecuentemente su periplo con la idea previa de rentabilizar su estancia en el extranjero, para lo que resume sus vivencias en un libro cuyo contenido habrá de ajustar a las demandas de la época, lo que le ayudará a resarcirse, en todo o en parte, de los gastos ocasionados.

Teniendo esto en cuenta, es necesaria una cierta prevención con las opiniones de estos viajeros, en particular con las de los franceses, pues sienten una cierta inclinación a caricaturizar o resaltar los aspectos negativos o escandalosos del país ${ }^{38}$. La realidad es que muchos de ellos realizaron sólo viajes relámpago por la Península e, incluso, algunos es posible que ni llegaran a poner pie en suelo español ${ }^{39}$.

De este modo, los “curiosos impertinentes" del XVIII que visitan España mencionan casi siempre el fandango, pero no porque sea el baile de moda de la época, sino porque resume la opinión negativa que los extranjeros tienen sobre el carácter español ${ }^{40}$. Además de que sus visiones suelen estar llenas de prejuicios y ser muy poco objetivas, muchos de ellos apenas tienen idea de música o de danza, por lo que acostumbran a inspirarse en las descripciones de autores anteriores. Con estas premisas, iniciamos nuestra búsqueda del rastro de la epístola, convirtiendo las líneas que siguen en un pequeño viaje a través de la bibliografía.

36 GÓMEZ (1998-1999): 127-168.

37 PLAZA (1999).

38 TAMARIT (2003).

39 TORRIONE (1992).

40 ETZION (1993): 229-250. 
El diplomático e historiador Jean François Peyron (17481784) es probablemente el primero en asociar la carta de Martí con el fandango $o^{41}$. En su obra Essais sur l'Espagne. Voyage fait en 1777 et 1778, où l'on traite des moeurs, du caractère, des monuments, du commerce, du théâtre, et des tribunaux particuliers à ce royaume (Ginebra, 1780) ${ }^{42}$, dedica un capítulo a la ciudad de Cádiz, y en él alude a las famosas puellae gaditanae, de las que, afirma, eran requeridas en la antigua Roma «dans les fêtes publiques et les orgies particulières, tant pour leur habileté à toucher divers instruments, que pour leur talent pour la danse, et leur humeur pleine d'enjouement $»^{43}$.

Y todavía hoy, continúa nuestro autor, hacen gala de su gran poder seductor:

elles savent varier avec autant de délicatesse que de lasciveté, les attitudes voluptueuses, et quelquefois cyniques des danses du pays; il en est même qui ne peuvent être exécutées dans les assemblées jalouses d'unir la décence au plaisir. Mais on ne peut concevoir leur légèreté, et surtout la mollesse et la flexibilité de leurs mouvements ${ }^{44}$.

Remite de inmediato a la descripción « aussi élégante qu'expressive » que el deán Martí hizo de la danza de Cádiz que, añadePeyron, «est vulgairement nommée le Fandango». Nos parece importante destacar este hecho, pues seguramente es la primera vez que la descripción del deán se asocia de modo inequívoco con el fandango. A pie de página recoge, prácticamente en su integridad ${ }^{45}$, la carta original en

41 SWINBURNE (1787): vol. I, 137, da muestras de conocer el epistolario de Martí, de quien cita una de sus cartas en la que describe el teatro de Sagunto. Sin embargo, y a pesar de dedicar algunos pasajes al fandango (SWINBURNE (1787): vol. I, 70 y 353), especialmente esta última, donde asegura que en Cádiz el fandango se baila "a la ley", es decir, "in all the perfection it is capable of") no menciona la carta del deán.

42 PEYRON (1780). Dos años después volvió a publicarse bajo el título de Nouveau voyage fait en Espagne, en 1777 et 1778. Londres, P. Elmsly/ París, P. Théophile Barrois, 1782.

43 PEYRON (1780): vol. I, 246: "En las fiestas públicas y en las orgías privadas, tanto por su habilidad para tocar diversos instrumentos como por su talento para la danza y su sentido del humor repleto de gracia".

44 PEYRON (1780): vol. I, 246: "Saben variar con tanta delicadeza como lascivia las posturas voluptuosas y, algunas veces, desvergonzadas de los bailes del país; mira si es que no pueden ser ejecutados en aquellas asambleas que cuidan por unir la decencia con el placer. Sin embargo, no podemos concebir su ligereza, y sobre todo lo delicado y flexible de sus movimientos".

45 Tan sólo falta la postdata: "De reditu nostro ad vos...". En cuanto al texto latino, detectamos algunas variantes respecto a la edición original, debidas a algún leve cambio ("me hercule" por "me-hercules"), omisión ("ingenio loci" por "ingenioque loci") o error ortográfico ("contubesco" por "contabesco"); todas ellas en el último párrafo. Destacar también un cambio de puntuación en el párrafo donde Martí describe la danza: "clunium motationes, micationes femorum, salacium latín, que no traduce al francés, tal vez por lo escabroso de su contenido ${ }^{46}$. No obstante, consuela, « ce que j'ai dit de la souplesse des Andalouses suffit pour en donner une idée aux personnes qui n'entendent pas le latin ${ }^{47} »$.

Después de Peyron, será un polifacético y controvertido personaje, militar de profesión, Jean-Marie-Jerôme Fleuriot, también conocido como marqués de Langle (1742 /1749-1807), quien recoja de nuevo la carta de Martí en su Voyage de Figaro en Espagne. Siguiendo la línea establecida por Peyron, asegura que « le Fandango est trés ancien ». Y resalta, tal y como hicieran Marcial y los Carmina Priapea respecto al baile de las puellae gaditanae, su naturaleza casi afrodisiaca, tan poderosa que hasta haría dudar a un ermitaño de su estilo de vida:

$\mathrm{Ni}$ ces pyrrhiques voluptueuses tant courues des Romains, ni ces pantomimes dont parle Homère, ni ces danses des Saliens, tant célébrées par Denis d'Halycarnasse, n'approchèrent jamais du Fandango. Non, l'anachorète qui mange le plus de laitue, qui prie le plus, ne verrait pas danser le Fandango sans soupirer, sans être ému, et sans donner au diable ses voeux, son cilice et ses sandales ${ }^{48}$.

En el apartado de notas reproduce -como ya hiciera Peyron, que es casi con toda seguridad su fuente- la descripción de Martí; tan escandalosa -se excusa- que opta por no traducirla:

Voici la description voluptueuse que le P. Marti nous donne de cette danse fameuse; je n'ose pas la traduire ${ }^{49}$.

En 1809, Étienne-François de Lantier (1734-1826) publica en París su Voyage en Espagne du chevalier Saint-

insultuum imagines" que en Peyron se lee: "clunium motationes, micationes femorum salacium, insultuum imagines", es decir, el adjetivo "salax" se relaciona con "femur" y no con "insultus".

$46 C f$. TORRIONE (1992): 12.

47 PEYRON (1780): vol. I, 246 "Lo que he comentado acerca de la flexibilidad de las andaluzas basta para dar una idea a las personas que no entiendan el latín".

48 FLEURIOT (1796): 79 [1ª ed., Saint-Malo, 1784]: "Ni las voluptuosas danzas pírricas tan frecuentes entre los romanos, ni las pantomimas de las que habla Homero, ni las danzas de los salios tan celebradas por Dioniso de Halicarnaso se aproximarán nunca al fandango. No, el anacoreta que come más lechuga, el que reza más, no vería bailar el fandango sin suspirar o sentirse emocionado, sin mandar al diablo sus votos, su cilicio y sus sandalias". Acerca de las danzas de la Grecia y Roma clásicas, véase el artículo "saltatio" en DAREMBERG \& SAGLIO (1962): vol. IV, 1025 y ss.

49 FLEURIOT (1796): 243 "He aquí la voluptuosa descripción que el padre Martí nos ofrece de esta danza; yo no me atrevo a traducirla". 
Gervais $^{50}$, una obra que habría que considerar más una novela que un libro de viajes; es posible, incluso, que su autor no hubiera visitado en realidad España ${ }^{51}$. A pesar de todo, se incluye en ella una elegante y plástica descripción del baile del fandango, que imagina como una suerte de combate amoroso $^{52}$ en el que los bailarines huyendo y persiguiéndose sucesivamente llevan a cabo sugerentes movimientos plenos de sensualidad. Nada más sonar los primeros acordes

...les danseurs s'élancent dans la carrière; les uns armés de castagnettes, les autres fessant claquer leurs doigts pour en imiter le son: les femmes surtout se signalèrent par la mollesse, la légèreté, la flexibilité de leurs mouvements et la volupté de leurs attitudes; elles marquent la mesure avec beaucoup de justesse, en frappant le plancher de leurs talons: les deux danseurs s'agacent, se fuient, se poursuivent tour-à-tour; souvent la femme, par son air de langueur, par des regards pleins du feu du désir, semble annoncer sa défaite. Les amants paraissent prêts à tomber dans les bras l'un de l'autre; mais tout-à-coup la musique cesse, et l'art du danseur est de rester immobile: quand elle recommence, le fandango renait aussi ${ }^{53}$.

En nota a pie de página cita un fragmento de la carta de Martí, aquí nombrado, tal vez por un error tipográfico, Mouti ${ }^{54}$ :

\section{LANTIER (1809)}

51 Vid. FERNÁNDEZ (1974): 274.

52 BOURGOING (1789): vol, II, 307-308, describe también el fandango, cuyas escenas, afirma, son «véritables combats de Cythère», "auténticos combates citereos", en alusión a Venus, la diosa del amor.

53 LANTIER (1809): 267-268: "Los bailarines se lanzan a la carrera, unos armados con castañuelas, otros haciendo chasquear sus dedos para imitar el sonido. Destacan en especial las mujeres por la suavidad, la ligereza, la flexibilidad de sus movimientos y la voluptuosidad de sus gestos; marcan el compás con gran precisión, golpeando el suelo con los talones. Los dos bailarines se provocan, huyen, se persiguen alternativamente. A menudo la mujer, por su aire lánguido y sus miradas llenas del fuego del deseo, parece anunciar su derrota. Los amantes parecen dispuestos a caer en los brazos el uno del otro. Pero, de pronto, la música se detiene, y el arte del bailarín es quedarse quieto; cuando se inicia de nuevo, el fandango renace también".

54 LABORDE (1809): vol. V, 339 y ss., incluye también unas interesantísimas notas sobre el fandango, un baile que, según él, ya ha pasado de moda por esas fechas. No cita a Manuel Martí a propósito de este baile, pero demuestra conocerlo pues lo incluye en una relación de nombres ilustres españoles aunque, sorprendentemente, lo llama Barthélemy Marti “connu plus particulièrement sous le nom de Doyen d'Alicante" (LABORDE (1809): vol. V, 142). XIMENO (1774): vol. I, 66 , recoge la biografía de un tal Bartolomé Martí, que fue cardenal del título de Santa Águeda. Tal vez esto pudiera explicar la confusión de Laborde. Más recientemente, TORRIONE (1992): 13) también confunde el nombre de pila del deán, al que llama "José Martî", como el poeta y político cubano.
Un docteur Mouti a décrit le fandango dans une lettre dont voici quelques phrases: «Saltant vir et foemina, vel bini, vel plures, corpora ad musicos modos, per omnia libidinum irritamenta versantur. Membrorum in ea mollissimi flexus. Cunium mutationes, micationes femorum salacium. Omnia denique turgentis lasciviae, solertissimo studio expressa simulacra ${ }^{55} »$.

Los testimonios anteriores asocian la descripción de Martí con el baile del fandango; pero no siempre es así. Tal sucede con el antropólogo, naturalista y doctor en medicina francés, Julien-Joseph Virey (1775-1846), que aparentemente se inclina por relacionarla con la calenda, un baile de los negros de Guinea -afirma- todavía más lascivo que el fandango. Forzados como esclavos a ir a la América española, la población guineana lo habría llevado con ellos, terminando por propagarse entre los españoles:

On connaît en Espagne le bolero et le fandango, qui retracent des images voluptueuses, et que les anciens Romains se plaisaient à faire danser par les jeunes filles de Cadix, comme un irritamentum Veneris languen$t i S^{56}$; mais la calenda est une danse bien plus lascive encore des nègres d'Ardra en Guinée; ils l'ont apportée avec eux dans l'Amérique espagnole, et l'on y voit jusqu'à des religieuses espagnoles en être si transportées, qu'elles la dansent même dans les églises et les processions ${ }^{57}$.

En nota al pie alude a Martí (aquí nombrado "Martín”), de cuya carta recoge un amplio fragmento tomado posiblemente de Fleuriot, pues lo cita como fuente:

55 LANTIER (1809): 268: "Un tal doctor Mouti ha descrito el fandango en una carta, de la que he aquí algunas frases: "Saltant vir et foemina etc.".

56 Esto es, como un afrodisiaco o estimulante del apetito sexual; cf. JUVENAL, Sátiras XI 167.

57 VIREY (1825): 34-35: "En España se conoce el bolero y el fandango, que rememoran imágenes voluptuosas, y que los antiguos romanos se complacían en hacerlos bailar a las jovencitas de Cádiz, como un irritamentum veneris languentis. Pero la calenda es un baile todavía incluso más lascivo de los negros de Ardra en Guinea; lo llevaron con ellos a la América española, y allí se lo ve hasta entre las religiosas españolas que, al sentirse tan arrebatadas, incluso lo bailan en las iglesias y en las procesiones". Esta cita se incluye también en el Dictionaire de sciences médicales, una colosal obra en 60 volúmenes y unas 35.000 páginas editada por Charles Louis Fleury PANCKOUCKE entre 1812 y 1822, cuyos artículos fueron redactados por las personalidades más relevantes de la época, como Jean-Louis Alibert, Philippe Pinel, Jean Étienne Dominique Esquirol, Théophile René Hyacinthe Laennec o J. J. Virey; $c f$. JESCHKE, VETTERMANN, \& HAITZINGER (2009): 90. 
Le doyen Martin de Alicante décrit en ces termes cette danse lubrique: «Saltationis modus hoc ritu peragitur... Interea omnia constrepunt cachinnis et ronchis etc. $»^{58}$.

Virey reproduce el mismo pasaje en otro de sus títulos, Histoire naturelle du genre humain, concretamente en el artículo que dedica a las mujeres de raza negra, perteneciente a la primera sección de la obra, "Consideraciones fisiológicas sobre el sexo femenino" 59 . No obstante, esta obra conoció diferentes ediciones, y en una de las primeras hemos dado con otro fragmento que nos deja en la duda de si Virey asocia la descripción de Martí con la calenda o con el fandango. En él habla de la diferente naturaleza de la danza según el clima de cada país:

La danse, que les nations policées ont adoucie et rendue, pour ainsi dire, abstraite, fut usitée au nord pour échauffer les corps par les mouvements qu'elle exige; elle devint, comme la pyrrhique, la vive image du génie guerrier ou chasseur de ses peuples. Sous un ciel plus pur et plus doux, elle fut un simulacre énergique de la volupté, la pantomime de l'amour, comme le fandango espagnol et arabe, et les mouvements ioniques des anciennes grecques et romaines, ou des bayadères de l'Inde ${ }^{60}$.

Virey argumenta que el clima influye de manera determinante en el comportamiento moral de los hombres, razón que explica que la danza se convierta en las zonas más templadas en un enérgico simulacro del deseo. Y, en nota a pie de página, pone como ejemplo la calenda, una « danse des nègres de l'Amérique espagnole, [qui] a été apportée d'Afrique et communiquée aux espagnols ». Pero, también

58 "El deán Martín de Alicante describe esta danza lúbrica en estos términos: Saltationis modus hoc [...] cachinnis et ronchis etc."

59 VIREY (1834): vol. IV, 34-35. En el volumen II de una edición anterior de esta obra leemos una descripción similar de la calenda. En ella no cita a Martí pero sí añade un comentario sobre el efecto que esta danza ocasiona en los músculos del cuerpo: «La calenda est une danse lascive surtout des nègres d'Ardra en Guinée; ils l'ont apportée avec eux dans l'Amérique espagnole, et l'on voit jusqu'à des religieuses espagnoles en être si transportées, qu'elles la dansent même dans les églises et les processions. Par cette danse, tous les muscles du corps frissonnent de volupté, et s'agitent sous l'impression d'une jouissance universelle» (VIREY (1824): vol. II, 153-154)

60 VIREY (1801): 101-102: "La danza, que las naciones civilizadas han pulido y vuelto, por así decirlo, abstracta, fue empleada en el norte para dar calor a los cuerpos por los movimientos que implica; en el caso de la pírrica, se transformó en la viva imagen del espíritu guerrero o cazador de sus pueblos. Bajo un cielo más puro y más benigno, fue un enérgico simulacro de la voluptuosidad, de la pantomima del amor, como el fandango español y árabe, y los movimientos jónicos de los antiguos griegos y romanos, o las bayaderas de la India". en nota al pie, aparentemente en relación al "fandango español y árabe", añade:

Le doyen Marti a donné, en 1712, une bonne description de cette danse à Cadix, où elle est plus vive et même plus cynique qu'ailleurs. Les romains ne recherchoientils pas, selon Juvenal, les jeunes filles de cette ville pour cela même? Les femmes andalouses son renommées par leurs attitudes voluptueuses et lascives, et par leur extrême souplesse dans tous les exercices de volupté: Saltationis modus hoc ritu peragitur -dit Marti; saltant vir et foemina... ${ }^{61}$.

De modo que Virey comenzó relacionando la descripción de Martí con el fandango para, con el paso de los años, terminar haciéndolo con la calenda. Al fin y el cabo, como veremos, se trata al parecer de danzas no muy alejadas la una de la otra.

Una sección de este obra de Virey, "Histoire naturelle de l'espèce nègre en particulier", fue traducida al inglés por J. H. Guenebault con el título de Natural History of the Negro Race. En los mismos términos que Virey, describe la calenda como

a sort of lascivious dance [...] very common among the negroes, especially those of Ardra of Guinea, who have introduced it into the Spanish possessions of America ${ }^{62}$.

Y a pie de página menciona la carta del deán, cuya descripción identifica con esta danza:

Dr. Marti has given in 1712, a description of this dance at Cadiz, where it is more obscene than anywhere else: Corpora ad musicos modos per omnia libidinum irritamenta versantur [...] crissare foeminam, etc ${ }^{63}$.

La obra de Virey conoció también traducción al castellano. En efecto, fue vertida por el catedrático de griego,

61 VIREY (1801): 102-103: "El deán Martí dio, en 1712, una buena descripción de este danza en Cádiz, donde es más intensa, y más desvergonzada incluso, que en cualquier otro lugar. ¿No buscaban los romanos, según Juvenal, por esto mismo a las chicas jóvenes de esta ciudad? Las mujeres andaluzas son famosas por sus posturas voluptuosas y lascivas, y por su extremada flexibilidad en todos los ejercicios de voluptuosidad".

62 GUENEBAULT (1837): 89: "Una clase de danza lasciva [...] muy común entre los negros, especialmente entre los de Ardra en Guinea, que fue introducida en las posesiones españolas de América".

63 GUENEBAULT (1837): 90: "El Dr. Martí dio, en 1712, una descripción de esta danza en Cádiz, donde es más desvergonzada que en cualquier otro lugar: Corpora ad musicos etc." 
traductor de obras científicas, impresor y también Rector de la Universidad de Barcelona Antonio Bergnes de las Casas (1801-1879) ${ }^{64}$. En el párrafo que extractamos se menciona el carácter lascivo y licencioso de los bailes de los negros:

Por toda la tierra el hombre expresó siempre sus impulsos ya de alegría, ya de amor y pesar, por medio de la danza y la pantomima. Bajo los cielos ardientes del Mediodía todo promueve el deleite, por eso los bailes de los negros son lascivos y licenciosos; tales son la calenda, por la cual se les ve tan apasionados; la chega (chica en el Brasil), danza de los negros mozambiques de la isla de Francia, que se asemeja al fandango, y degenera en asqueroso desenfreno; esta danza representa todos los cambiantes del amor, desde la declaración hasta el triunfo del amante inclusive; al son del tamtam; tales son sobre todo aquellas danzas lascivas de las bailarinas, entre los pueblos asiáticos, y los voluptuosos ademanes de las almés y gavasies, en Egipto y Oriente. Los meneos más incitativos, las posturas más libres, manifiestan los arrebatos de la pasión que representan aquellos bailes ${ }^{65}$.

En nota a pie de página menciona la carta del deán, aunque no queda del todo claro si se asocia su descripción a la calenda, a la chica o, en general, a cualquier tipo de danza de carácter lascivo:

El doctor Martí dio, en 1712, una descripción de esta danza, tal y como la vio en Cádiz, donde es mas desaforada y cínica que en otras partes; dice así: Corpora ad musicos modos per omnia libidium irritamenta versantur [...] et cum quodam gannitu crissare foeminam, etc. Tales eran también sin duda aquellos movimientos y meneos jónicos de las antiguas griegas y romanas de que habla Horacio $[\ldots]^{66}$.

Es evidente que algún parecido encontrarían los observadores entre la calenda, la chica y el fandango, al menos en la versión más primitiva y menos refinada de éste ${ }^{67}$; o bien,

64 Sobre Bergnes véase el trabajo de CAMÓS (1998): 633-651. 65 VIREY (1846): vol. II, 413-414.

66 VIREY (1846): vol. II, 414.

67 El viajero inglés Richard Twiss (TWISS (1775): 156) asegura que hay dos tipos de fandango: "There are two kinds of fandangos, though they are danced to the same tune: the one is the decent dance; the other is gallant, full of expression, and, as a late French author energetically expressed it «est mêlée de certaines attitudes qui offrent un tableau continuel de jouissance". El autor francés al que alude Twiss es el abad Delaporte, que comenta a propósito de los bailes más populares de España: "La danse est, pour les espagnols, un divertissement si agréable, que les personnes les plus âgées ne veulent être exclues d'aucune fête. [...] Celles [les danses] qui sont le plus en usage, se nomment Faldango no hay que descartarlo, entre ambas danzas y la descripción de Martí, identificada con el fandango.

Uno de los primeros en relacionar la chica con el fandango fue el estadista francés Moreau de Saint-Méry (1750-1819), nacido en la isla de la Martinica, en las Antillas francesas. En un artículo sobre la danza, publicado en Filadelfia en 1796 (aunque, según afirma el propio autor en el preámbulo, fue redactado en 1789), afirma con rotundidad que la chica no es otra cosa que el fandango, sólo que menos desarrollado. Sin embargo, para él el origen de este baile no sería negro sino que habrían sido los moros quienes lo introdujeron en España:

L'Amérique n'a pas été la seule qui ait reçu, à cet égard, l'influence de l'Afrique, puisque les maures ont rendu propre à l'Espagne la passion de le fandango, qui n'est autre chose que le chica, seulement un peu moins développé (Danse. Philadelphie, 1796, p. 56) ${ }^{68}$.

El propio Moreau de Saint-Méry, en una obra publicada un año más tarde, un estudio sobre la isla de Santo Domingo, pinta de un modo harto gráfico el baile de la calenda y la chica, calificados ambos de lascivos por los continuos movimientos de muslos y caderas de los participantes. Comienza por la calenda:

Des danseurs et des danseuses, toujours en nombre pair, vont au milieu du cercle (qui est formé dans un terrain uni et en plein air) et se mettent à danser. Chacun affecte une danseuse pour figurer devant elle. Cette danse [...] consiste dans un pas où chaque pied est tendu et retiré successivement en frappant avec précipitation, tantôt de la pointe et tantôt du talon sur la terre, d'une manière assez analogue au pas de l'anglaise. Le danseur tourne

(sic) et Seguidilla. La première est grave, galante, pleine d'expression, et mêlée de certaines attitudes qui offrent un tableau continuel de jouissance. La seconde est accompagnée de chants, et se danse deux à deux comme la première, mais avec plus de gaieté et moins d'indécence" (cf. DELAPORTE (1772): vol. XVI, 105-106). Sin embargo, es muy probable que el abad no hubiera visitado en realidad España, por lo que su testimonio sería fruto de la erudición y no del conocimiento de primera mano; $c f$. SARRAILH (1934): 29-70; y ORTAS (2005): 48-91. Por otra parte, no está mal recordar el comentario de Juan Antonio de Iza Zamácola, "don Preciso", a propósito de la estilización de los bailes populares que, al menos, nos induciría a pensar en una evolución estilística del baile del fandango: "Don Pedro de la Rosa... como hombre que había adquirido un perfecto conocimiento del arte de danzar, reduxo las seguidillas y el fandango a principios y reglas sólidas» ( $c f$. DON PRECISO (1799): vol. I, Discurso, XVIII).

68 MOREAU DE SAINT-MÉRY (1796): 56: “América no ha sido la única en recibir, a este respecto, la influencia de África, ya que los moros en propiedad han aportado a España la pasión por el fandango, que no es otra cosa que la chica, sólo que un poco menos desarrollado". 
sur soi-même ou autour de sa danseuse qui tourne aussi et change de place en agitant les deux bouts d'un mouchoir qu'elle tient. Le danseur abaisse et lève alternativement ses bras en gardant les coudes près du corps et le poing presque fermé ${ }^{69}$.

\section{Y continúa con la chica:}

Une autre danse nègre, à Saint-Domingue, qui est aussi d'origine africaine c'est le chica, nommé simplement calenda aux Iles du Vent, congo à Cayenne, fandangue en Espagne, etc. Cette danse a un air qui lui est spécialement consacré et où la mesure est fortement marquée. Le talent pour la danseuse est dans la perfection avec laquelle elle peut faire mouvoir ses hanches et la partie inférieure de ses reins en conservant tout le reste du corps dans une espèce d'immobilité que ne lui fait même pas perdre les faibles agitations de ses bras qui balancent les deux extrémités d'un mouchoir ou de son jupon. Un danseur s'approche d'elle, s'élance tout-à-coup, et tombe en mesure, presqu'à la toucher. Il recule, il s'élance encore et la provoque à la lutte la plus séduisante. La danse s'anime et bientôt elle offre un tableau dont tous les traits d'abord voluptueux, deviennent ensuite lascifs. Il serait impossible de peindre le chica avec son véritable caractère, et je me bornerai à dire que l'impression qu'il cause est si puissante que l'africain ou le créole, de n'importe quelle nuance, qui le verrait danser sans émotion passerait pour avoir perdu jusqu'aux dernières étincelles de la sensibilité ${ }^{70}$.

69 MOREAU (1797): vol. I, 45: "Los danzarines y las danzarinas, siempre en igual número, llegan al centro de un círculo (que se ha formado en un terreno llano al aire libre) y comienzan a bailar. Cada uno se dirige a una danzarina para realizar delante de ella una figura. Esta danza [...] consiste en un paso en el que cada pie se tiende y se levanta sucesivamente golpeando con precipitación sobre el suelo, tanto con la punta como con el talón, de un modo bastante parecido al paso inglés. El danzarín gira sobre sí mismo o alrededor de su danzarina, que también gira y cambia de posición, agitando las dos puntas de un pañuelo que ella lleva. El danzarín baja y sube alternativamente sus brazos, manteniendo los codos pegados al cuerpo y el puño casi cerrado".

70 MOREAU (1797): vol. I, 45: "Otra danza negra de Santo Domingo, que es también de origen africano, es la chica, denominada sencillamente calenda en las islas de Barlovento, congo en Cayena, fandango en España, etc. Esta danza tiene una melodía especialmente destinada a ella, con un compás fuertemente marcado. El talento de la bailarina reside en la perfección con que consiga hacer mover sus caderas y la parte inferior de sus riñones mientras conserva el resto del cuerpo en una especie de inmovilidad que ni incluso le hacen perder las débiles sacudidas de sus brazos que balancean los dos extremos de un pañuelo o de su enagua. Un danzarín se aproxima a ella, salta de repente en el aire y cae apropiadamente, casi hasta tocarla. Se separa, salta otra vez y la incita a la lucha más seductora. La danza se anima y pronto ofrece un cuadro en el que todos los trazos, hasta el momento voluptuosos, devienen enseguida lascivos. Sería imposible describir la chica en su verdadero carácter; me limitaré a decir que la impresión que
Tal y como señala Janheinz Jahn ${ }^{71}$, la descripción de la chica de Moreau de Saint-Méry coincide bastante con la descripción de la calenda que presenciaría bailar en 1698 el misionero dominico francés Jean-Baptiste Labat (16641738) durante su viaje por las Antillas ${ }^{72}$ :

Les danseurs sont disposez sur deux lignes, les uns devant les autres, les hommes d'un côté, et les femmes de l'autre. [...] A l'égard des danseurs, ils tiennent les bras à peu près comme ceux qui dansent en jouant des castagnettes. Ils sautent, font des virevoltes, s'approchent à deux ou trois pieds les uns des autres, se reculent en cadence jusqu'à ce que le son du tambour les avertisse de se joindre en se frappant les cuisses les uns contre les autres, c'est-adire, les hommes contres les femmes. A les voir, il semble que ce soient des coups de ventre qu'ils se donnent, quoiqu'il n'y ait cependant que les cuisses qui supportent ces coups. Ils se retirent dans le moment en pirouettant, pour recommencer le même mouvement avec des gestes tour-à fait lascifs, autant de fois que le tambour en donne le signal, ce qu'il fait souvent plusieurs fois de suite. De tems en tems ils s'entrelacent les bras, et font deux out trois tours en se frappant toujours les cuisses, et se baisant ${ }^{73}$.

produce es tan fuerte que un africano o un criollo, no importa el color, que la vea danzar y no se emocione se considerará que ha perdido hasta la última chispa de su virilidad".

71 JAHN (1970): 93.

72 De regreso a Europa en 1705, el padre Labat recaló en Cádiz donde, especula FERNÁNDEZ (1974): 49, presenciaría bailar el fandango, y sería el dominico el primero en mencionar esta danza. Sin embargo, nosotros no hemos encontrado pruebas que sostengan tal afirmación, pues el padre Labat no hace mención alguna del fandango ni en su Nouveau Voyage aux isles Françoises de l'Amérique (Paris, Giffart, 1722) ni en su Voyage en Espagne et en Italie (Amsterdan, 1731), obra esta última en la que narra su llegada a tierras gaditanas tras retornar de las Américas. Cosa diferente sería si se diese por hecho que la calenda y el fandango son una misma danza. Tanto TORRIONE (1992): 12, como ETZION (1993): 243, nota 52, se hacen eco de la afirmación de Fernández Herr, que aparentemente dan por válida.

73 LABAT (1724): vol. IV, 155-156 [1 $1^{\text {a }}$ ed., Paris, Giffart, 1722] "Los danzarines se colocan en dos filas, unos frente a otros, los hombres de un lado y las mujeres al otro [...] En cuanto a los danzantes, levantan un poco sus brazos, como quienes bailan tocando las castañuelas. Brincan, hacen piruetas, se aproximan hasta estar a dos o tres pies de distancia unos de otros, retroceden siguiendo el compás hasta que el sonido del tambor les indica que se acerquen juntando sus muslos unos con otros, esto es, los hombres contra la mujeres. Viéndolos, parece que se trata de choques que ellos se dan con el vientre, cuando realmente son los muslos los que sufren el choque. Con una pirueta se retiran en seguida, para comenzar de nuevo el mismo movimiento con gestos, de hecho, lascivos, siempre que el tambor da la señal, cosa que ahora sucede varias veces. De vez en cuando entrelazan sus brazos, y dan así dos o tres vueltas, golpeándose siempre los muslos, y se besan”. 
Curiosamente, estas descripciones de la chica y la $c a$ lenda, así como la de Martí, guardan cierta semejanza con lo que el padre Juan de Mariana (1536-1623) dice de la deshonesta zarabanda:

[...] ha salido estos años un baile y cantar tan lascivo en las palabras, tan feo en los meneos, que basta para pegar fuego aun a las personas muy honestas. Llámanle comúnmente zarabanda [...] se representan, no solo en secreto, sino en público, con extrema deshonestidad, con meneos y palabras a propósito los actos más torpes y sucios que pasan y hacen en los burdeles, representando abrazos y besos y todo lo demás con boca y brazos, lomos y con todo el cuerpo, que solo el referirlo causa vergüenza $[\ldots]^{74}$.

El jesuita se hace eco incluso de la posible antigüedad del baile, acordándose de las puellae gaditanae:

No dejaré de decir lo que me avisó un amigo mío, que este baile se hacía antiguamente en tiempo de romanos, y que también había salido de España, tierra fértil en semejantes desórdenes, por donde las mujeres que hacían este baile de deshonestidad las llamaban en Roma gaditanas, de Cádiz, ciudad de España, donde se debió de inventar en aquel tiempo ${ }^{75}$.

Como Moreau de Saint-Méry, el francés Jacques Arago (1790-1855), hermano del matemático, físico y astrónomo François Arago (1786-1853), también se inclina por relacionar la chica con el fandango:

On désigne généralement leurs danses sous le nom de Chéga ou Tchéga (Chica au Brésil), danse Mosambique qui a quelque rapport avec le Fandango $^{76}$.

Y tanto Moreau de Saint-Méry como el propio Arago son recordados por Auguste Alexis Floreal Baron (17941862), miembro fundador de la Universidad Libre de Bruselas, profesor de historia y literatura moderna. Baron escribió

74 MARIANA (1854): 433. A este respecto, Pellicer considera el fandango un vástago de la zarabanda: "No es dudable que la zarabanda, que antiguamente fue a Roma, y después resucitó en España, ha dejado sucesión pestífera de su obsceno matrimonio con su marido Antón Pintado, y que los bailes vivos y peligrosos, como el fandango, el agua de nieve, la guaracha, la alemanda, etc., son retoños y renuevos suyos"; $c f$. PELLICER (1804): Parte primera, 138-139.

75 MARIANA (1854): 433.

76 ARAGO (1822): vol. I, 222: "Por lo general, se designan sus danzas con el nombre de chega o tchega (chica en Brasil), una danza mozambiqueña que tiene una cierta relación con el fandango". un tratado de danza en el que, hablando de las bayaderas, nombre que reciben las bailarinas y las cantoras de la India, afirma:

Une chose singulière, c'est qu'à l'exception des motifs religieux, tous les détails de la danse des Bayadères, se retrouvent dans les pays chauds de l'Europe et de l'Afrique, et qu'on la nomme Fandango, Bolero ou Tchega. M. Moreau de Saint-Méry, dans son libre sur les danses des colonies, et M. Arago, dans sa Promenade autour du Monde, nous en ont conservé les principaux traits $^{77}$.

Es la misma idea que recoge el que fuera primer bailarín en el King's Theatre y afamado compositor de ballets, Carlo Blasis (1797-1878), en su tratado de danza; aunque sospechamos que Blasis no hace sino traducir a Moreau de Saint-Méry:

America is not the only country that has been influenced by Africa in dancing; for, from the Moors it was that Spain first received that dance now so peculiar to it, the Fandango, which is nothing else than the Chica, under a more decent form, the climate and other circumstances not permitting the performance of this latter with all its native concomitants ${ }^{78}$.

Ya con anterioridad, el polifacético Beaumarchais (1732-1799), en una carta inédita fechada en Madrid en 1764 y dirigida al duque de La Vallière, decía refiriéndose al fandango:

Le goût de cette danse obscène, qu' on peut comparer au calenda de nos nègres en Amérique, est si bien enraciné chez ce peuple $[\ldots]^{79}$.

77 BARON (1825): 41: "Una cosa singular, es que, a excepción de los motivos religiosos, todos los detalles de la danza de bayaderas, se reflejan en los países calientes de Europa y África, y se denomina fandango, bolero o tchega. El Sr. Moreau de Saint-Méry, en su libro sobre las danzas en las colonias, y el Sr. Arago, en su Viaje alrededor del mundo, nos han recordado sus principales características". La primera edición de la obra de Baron se publicó bajo el título de Entretiens sur la danse ancienne, moderne, religieuse, civile et théatrale, accompagnés d'une lithographie chorégraphique (BARON (1824)).

78 BLASIS (1830a): 28-29 “América no es el único país que se ha visto bajo la influencia de África en el baile; pues de los moros fue que España recibiera esa danza ahora tan peculiar, el fandango, que no es otra cosa que la chica bajo una apariencia más decente, al no permitir el clima y otras circunstancias la interpretación de esta última con todas sus concomitancias de origen".

79 BEAUMARCHAIS: "Lettre inédite écrite au duc de La Vallière, par Beaumarchais, à Madrid, le 24 décembre 1764", en LOMÉNIE (1856): vol. I, 507: "El gusto por esta danza obscena, que se puede 
En cualquier caso, y salvo las excepciones que hemos señalado, explicables por la estrecha relación que parece existir entre la chica y el fandango $o^{80}$, prevalece la tendencia a identificar la descripción del baile que dio Martí con este último. Así, François Fertiault (1814-1915), tras teorizar que el fandango es hijo de la chica, cita, entre otros testimonios, la carta del deán como ejemplo de descripción técnica del famoso baile:

...le fameux, l'illustre Fandango, cet enfant de la Chica des Africains ${ }^{81}$, cette danse dont le docteur Yriarte a dit: "le mélodieux Fandango, qui charme les âmes des naturels et des étrangers, des sages et des vieillards les plus austères" ${ }^{2}$; cette danse qu'ont décrite, en vers gracieux le célèbre cavalier Marino ${ }^{83}$, et en prose latine assez technique le moins célèbre doyen Marti; cette danse qui, dit-on, faillit être condamnée par un consistoire de la cour de Rome réuni dans ce but ${ }^{84}$, et qui, par son effet

comparar a la calenda de los negros de América, está muy bien arraigada en este pueblo [...]".

80 José Luis Navarro postula que, en su origen, el fandango fue uno más de los "bailes de negros", como el guineo, la zarabanda, la chacona o el zarambeque, que llegaron a España desde las Indias occidentales; $c f$. NAVARRO (2008): 114.

81 Previamente, Fertiault ha insistido en esta idea: «La Chica, pittoresque mais souvent trop expressive, née en Afrique, transportée aux Antilles, et qui a enfanté le séduisant Fandango [...]» ("la chica, pintoresca pero muchas veces expresiva en demasía, nacida en Africa, transportada a Las Antillas, y que ha dado a luz al fandango [...]"); $c f$. FERTIAULT (1854): 93.

$82 C f$. IRIARTE (1779): canto quinto, VI, 113: “¿En qué bárbaro clima/ Al baile no se anima/ Con diversos tañidos/ Por costumbre heredados, no aprendidos?/ Dígalo solamente/ El más usual en la española gente, / Que en dos compases únicos, ceñidos/ A medida ternaria/ Admitir suele exornación tan varia,/ Que en ella los primores/ Del gusto, ejecución y fantasía/ Apuran los mas diestros profesores:/ el airoso fandango, que alegría/ Infunde en nacionales y extranjeros, / En los sabios y ancianos más severos". La referencia a Iriarte, Fertiault parece tomarla de BLASIS (1830b): 16.

83 Se refiere a unos versos de la obra L'Adone, poema eroico (canto XX, "Gli Spettacoli") del poeta italiano Giambattista MARINO (1569-1625), aunque en ellos alude claramente a la zarabanda y la chacona, representantes ambas de danzas de carácter lascivo; $C f$. MARINO (1861), Opere del Cavalier Giambattista Marino... (1861): 412. Francisco Asenjo BARBIERI recoge y traduce dichos versos en su libro satírico Las castañuelas: estudio jocoso (BARBIERI (1878): 22 y ss.). Por otra parte, Fertiault toma de Blasis la referencia a Marino; $c f$. C. BLASIS (1830b): 16-17.

84 A finales del siglo XVIII circulaba una historia en la que se narraba la pretensión de unos religiosos de que el fandango fuera prohibido por el Papa, cómo éste pidió verlo bailar antes de condenarlo y ni él ni su cónclave pudieron resistirse a sus encantos. Como señala BEAUMARCHAIS en la carta arriba citada (LOMÉNIE (1856): 507), se trataba del argumento de una comedia muy celebrada por el pueblo; y lo mismo afirma Alexandre de LABORDE en su Itinéraire descriptif de l'Espagne (LABORDE (1808): vol. V, 340). Sin embargo, Jean-François BOURGOING, en su Nouveau électrique et entraînant, finit par faire danser ses juges eux-mêmes, lesquels, gagnés et vaincus, lui accordèrent sa grâce entière et le rétablirent si bien dans tous ses privilèges que, seul avec le Bolero, il a conservé l'honneur d'être dansé sur les théâtres d'Espagne; cette danse, disje, dont le nom signifie aller danser, qui s'exécute par deux personnes s'accompagnant des vifs roulements des castagnettes, et dont le mouvement rapide a fait dire que: "tout n'est que vie et action dans le Fandango" 0 . Les Espagnols disent encore que: "le Bolero enivre, et que le Fandango enflamme" $"$. Un voyageur, au style net et précis, ajoute: "Non, l'anachorète qui mange le plus de laitue, qui jeûne le plus, ne verrait pas danser le Fandango par Julie Formalaguez, sans soupirer, sans désirer, et sans donner au diable ses voeux, sa continence et ses sandales ${ }^{87} . . . " 88$.

Por cierto que esta cita aparece íntegra a pie de página en el sexto volumen de un curioso manual para buenas señoritas en el que, firmado por Fertiault, se incluye un artículo sobre las danzas extranjeras modernas. Y, como ya sucediera en el caso de Lantier, Martí aparece aquí erróneamente nombrado como "docteur Mouti"

voyage en Espagne (BOURGOING (1789): vol. II, 305-306) parece tomarlo por un suceso que realmente aconteció. Sobre esta leyenda, que también espoleó la imaginación de escritores extranjeros, Cf. FERNÁNDEZ (1974): 108; ETZION (1993): 237-238; y PLAZA (1999): 145.

85 Aunque no lo cita, la frase está tomada de una traducción francesa de la obra de BLASIS (1830b): 32.

86 Tomado de LANTIER (1809): 286

87 Tomado de FLEURIOT (1796): 79-80.

88 FERTIAULT (1854): 126-127: "El famoso, el ilustre fandango, ese hijo de la chica de los africanos, esa danza sobre la que el doctor Iriarte ha dicho: "el melodioso fandango, que cautiva el alma de naturales y extranjeros, de los sabios y ancianos más austeros"; esa danza que han descrito, en graciosos versos, el célebre caballero Marino, y en prosa latina muy técnica el menos célebre deán Martí; esa danza que, se cuenta, estuvo a punto de ser condenada por un consistorio de la corte de Roma reunido a tal fin y que, por su efecto electrizante y magnético, acabó por hacer bailar a los jueces mismos, lo cuales, ganados y vencidos, le concedieron su gracia entera y le restituyeron tan bien en todos sus privilegios que, sólo con el bolero, ha conservado el honor de ser danzado en los teatros de España; esta danza, digo, cuyo nombre significa "ir a bailar", que se ejecuta por dos personas que se acompañan con los vivos redobles de las castañuelas, y cuyo rápido movimiento ha hecho decir: "todo no es más que vida y acción en el fandango". Los españoles dicen todavía que "el bolero embriaga, pero el fandango inflama". Un viajero, en un estilo claro y preciso, añade: "No, el anacoreta que come más lechuga, el que reza más, no vería bailar el fandango a Julia Formaláguez sin suspirar, sin sentir deseo y sin mandar al diablo sus votos, su continencia y sus sandalias".

89 Cf. Le Conseiller des dames et demoiselle: journal d'économie domestique et de travaux a l'aiguille. Paris, Penaud Frères, 18521853,181 . 
En 1862 atraviesan La Junquera el aristócrata francés Charles Davillier (1823-1883) y el pintor Gustave Doré (1832-1883), decididos ambos a narrar sus experiencias por España a los lectores de la revista parisina Le Tour du Monde, especializada en relatos de viajes. Sus escritos e ilustraciones se publicaron por entregas entre 1862 y 1873 , editándose más tarde el relato completo bajo el título de Voyage en Espagne par Gustave Doré et le Baron Ch. Davillier ${ }^{90}$. En sendas crónicas del año 1862 incluye Davillier una interesantísima disertación sobre las danzas típicas del país ${ }^{91}$. Menciona, entonces, por primera vez al deán Martí, al que considera buen conocedor de las danzas en boga en su tiempo en Cádiz, que no serían otra cosa que las antiguas danzas de las que hablaban los clásicos, sólo que más perfeccionadas:

Le P. Marti, doyen d'Alicante, connaissait à fond les danses en faveur de son temps à Cadix, et qu'il appelait délices gaditanes, delicias gaditanas: si nous l'en croyons, c'étaient bien aussi les danses anciennes, mais très-perfectionnées, à tel point, que celles-ci et même la fameuse chordaxa phrygienne ne devaient être auprès que de simples bagatelles ${ }^{92}$.

Naturalmente, el fandango es de obligada referencia para un viajero extranjero; eso a pesar de haber sido ya hace tiempo desplazado por otros bailes, como el propio barón advierte. Davillier evidencia haberse informado convenientemente para bosquejar su descripción de esta danza, como se desprende de su referencia a Iriarte, que ya encontramos en autores anteriores como Blasis, Fertiault e incluso, más atrás en el tiempo, en Jean-François de Bourgoing (1748$1811)^{93}$. Y también resulta obvio que ha leído a Lantier, a quien, sin citar su nombre, identifica como "un autor del tiempo de la Restauración", en alusión al período, comprendido entre 1815 y 1830, que siguió a la caída de Napoleón. En efecto, de él toma aquel largo párrafo en el que describía de forma muy plástica el baile del fandango:

90 En España se publicó hace algunos años en edición facsímil: DAVILLIER (1974).

91 "Voyage en Espagne par MM. Gustave Doré et Ch. Davillier" (DAVILLIER (1866): 388-416).

92 DAVILLIER (1866): 390: "El padre Martí, deán de Alicante, conocía profundamente las danzas de Cádiz preferidas de su tiempo, y que él denomina delicias gaditanas (delicias gaditanas): si hemos de creerle, eran indudablemente las antiguas danzas, pero más perfeccionadas, a tal punto que aquellas e incluso la famosa cordax frigia en comparación no serían otra cosa que simples bagatelas".

93 Jean-François de Bourgoing (BOURGOING (1789): vol. II, 305-308) habla del fandango, del que ofrece una interesantísima descripción. Y también menciona a Tomás de Iriarte, "déjà connu par ses fables littéraires et son poème sur la musique" (BOURGOING (1789): vol. II, 380).
Un auteur du temps de la Restauration décrit la même danse, « bien digne d'être exécutée à Paphos ou à Gnide, dans le temple de Vénus ». - « L'air national du fandango, comme une étincelle électrique, frappe, anime tous les cœurs $[\ldots]^{94}$.

Más adelante vuelve a echar mano de Lantier, que recuerda una suerte de dicho popular con el que los españoles sintetizan el poder del bolero y del fandango; si bien Davillier atribuye la cita un "autor español":

Si les Espagnols sont passionnés pour le bolero, ils ne le sont pas moins pour le fandango, le bolero enivre, dit un auteur espagnol; le fandango enflamme ${ }^{95}$.

Afirma el barón que el fandango ya era conocido a fines del siglo XVIII, deducción a la que probablemente llega a la vista del testimonio del atrevido deán, que utiliza las perífrasis más singulares para mejor dibujar esos movimientos que tan bien resumen el casticismo "meneo":

Le fandango était déjà connu vers la fin du dixseptième siècle; un prêtre espagnol, nommé Marti, qui était doyen du chapitre d'Alicante, écrivait de Cadix, le 16 des calendes de février, une lettre en latin dans laquelle il donne la description du fandango: le brave doyen emploie les périphrases les plus étranges pour mieux dépeindre cet ensemble de mouvements qu'on appelle le meneo ${ }^{96}$.

Reproduce, a continuación, un amplio fragmento de la carta de Martí en traducción al francés. Es probablemente la primera vez que la carta se vierte, para su publicación, a una lengua moderna:

94 DAVILLIER (1866): 399-400: "Un autor del tiempo de la Restauración describe la misma danza, "muy digna de ser ejecutada en Pafos o en Gnido, en el templo de Venus". -"El aire nacional que es el fandango, como una chispa eléctrica golpea, anima todos los corazones". $C f$. LANTIER (1809): 267-268. Es interesante resaltar que cuando Lantier habla de "coups de talons", Davillier glosa con el casticismo "taconeos".

95 DAVILLIER (1866): 416: "Si los españoles sienten pasión por el bolero, no lo es menos por el fandango; el bolero embriaga, dice un autor español; el fandango inflama". $C f$. LANTIER (1809): 286: "Le fandango, disent les Espagnols, enflamme ; le volero enivre".

96 DAVILLIER (1866): 416: "Hacia finales del siglo XVII ya se conocía el fandango; un sacerdote español, de nombre Martí, que era deán del Capítulo de Alicante, escribió desde Cádiz, el 16 de las calendas de febrero, una carta en latín en la que ofrece la descripción del fandango: el valiente deán utiliza las perífrasis más extrañas para mejor reflejar ese conjunto de movimientos que llaman meneo". 
«Vous connaissez», dit le doyen Marti, «cette danse de Cadix, fameuse depuis tant de siècles par ses pas voluptueux, qu'on voit encore exécuter aujourd'hui dans tous les faubourgs et dans toutes les maisons de cette ville aux applaudissements incroyables des spectateurs; elle n'est pas seulement en honneur parmi les négresses et autres personnes de base condition, mais parmi les femmes les plus honnêtes et de la plus haute naissance».

«Ce pas est dansé tantôt par un homme et une femme tantôt par plusieurs couples, et les danseurs suivent la mesure de l'air avec les plus molles ondulations du corps... C'est vraisemblablement ainsi que jadis Hercule le devait danser avec son Omphale.»

«Cependant les rires bruyants et les gais éclats de voix se font entendre; bientôt les spectateurs eux-mêmes, atteints d'une joyeuse fureur comme dans les atellanes antiques, s'élancent pour jouer à leur tour un rôle actif, et se balancent en suivant les mouvements de la danse».

«Telles sont les délices des habitants de Cadix: ne pensez-vous pas que les danses de l'antiquité, telles que la chordaxa phrygienne, n'étaient auprès de celle-ci que de véritables bagatelles?»

«Et maintenant», ajoute le doyen d'Alicante, «blâmez donc la corruption des anciens, et osez louer la réserve de nos moeurs» ${ }^{97}$.

Como puede verse, Davillier se salta en su traducción el momento álgido de la descripción del deán, aquel en el que Martí detalla los sensuales movimientos de los bailarines, tal vez por considerarlo demasiado atrevido. Todavía una observación más y es que, alterando el orden original, deja para el final el párrafo con el que deán abría su carta.

Daremos ahora un considerable salto en el tiempo y, siguiendo el rastro que ha ido dejando la carta de nuestro deán, nos trasladaremos a la España de los años 30. En los

97 DAVILLIER (1866): 416: “Conoces -dice el deán Martí- esa danza de Cádiz, famosa después de tantos siglos por sus pasos voluptuosos, que todavía hoy se ve ejecutar en todos los barrios y en todas las casas de esta ciudad con el incré́ble aplauso de los espectadores; no solamente se la honra entre las negras y otras personas de baja condición, sino también entre las mujeres más honestas y de más alta cuna. Ese paso se baila unas veces por un hombre y una mujer, y otras por varias parejas, y los danzarines siguen el compás de la melodía con las más suaves ondulaciones del cuerpo [...] Es probable que antaño así debió bailarla Hércules con su Onfalia. Mientras tanto, las risas ruidosas y los gritos alegres se hacen oír; pronto los espectadores mismos, alcanzados por un alegre furor, como en las antiguas atelanas, se lanzan a su vez a jugar un papel activo, y se mecen siguiendo los movimientos de la danza. Tales son las delicias de los habitantes de Cádiz. ¿No crees que las danzas de la Antigüedad, tales como la cordax frigia, no eran en comparación a ésta sino meras bagatelas? Y ahora -añade el deán de Alicante- censura, pues, la corrupción de los antiguos y atrévete a alabar la mesura de nuestras costumbres." primeros años de esa década, Francisco Carreras y Candi (1862-1937) dirige la publicación de una magna obra titulada Folklore y Costumbres de España. El segundo volumen incluye un amplio capítulo bajo el enunciado de "El baile y la danza", redactado por el ilustre folklorista $\mathrm{Au}$ relio Capmany (1868-1954), que dedica, obviamente, un apartado al fandango ${ }^{98}$. Cita allí un amplio fragmento de la carta de Martí traducido al español. Como ya sucediera con Davillier, echamos en falta el comprometido párrafo de la carta, el más subido de tono, en el que el deán describe sin ambages los reprobables "meneos" de los bailarines. El porqué de esta ausencia, que achacamos en un primer momento a las limitaciones impuestas o autoimpuestas por mor de la censura, se aclaró nada más consultar la crónica del barón que es, aunque no lo cite, la principal fuente de Capmany ${ }^{99}$. En realidad, nuestro folclorista se limita a traducir del francés el fragmento de la carta de Martí, del que Davillier prefirió suprimir el incómodo párrafo. Hay un detalle, no obstante, que nos llama la atención y es que Capmany traduce "négresses" por "gitanas", lo que no deja de ser una interpretación.

Sea como fuere, el texto de Capmany es, junto con las obras de Peyron y Davillier, una pieza esencial en esta larga cadena de transmisión que ha hecho que la carta del deán Martí sea de obligada referencia cuando se habla del fandango. En las líneas que quedan intentaremos descubrir algunos otros eslabones de la cadena, los más cercanos a nosotros, autores la mayoría que enfocan sus trabajos al estudio e investigación sobre los orígenes musicales del flamenco.

Una de las últimas alusiones a la carta del deán de Alicante la hemos encontrado en un artículo firmado conjuntamente por Reyes Zúñiga y Hernández Jaramillo, en el que se resalta la importancia de la ciudad de Cádiz como lugar de desembarco de las músicas y bailes venidos allende los mares y, entre ellos, el fandango ${ }^{100}$. Puesto que confiesan no haber tomado la referencia de una fuente directa, los autores se muestran un tanto prudentes en cuanto a la datación de

98 CAPMANY (1988): 247-251 [1 $1^{\text {a }}$ ed., Barcelona, Alberto Martín, 1931-1933].

99 A. Baron, citado expresamente a propósito de la relación entre la chica (o tchega) y el fandango, es otra de las fuentes de Capmany (vid. BARON (1825): 41). En cuanto a la descripción que Capmany da del baile del fandango está tomada de Étienne-François de Lantier (LANTIER (1809):267 y ss.), citado también por Davillier, de quien probablemente lo toma Capmany, si bien nuestro folclorista atribuye la cita no a un "autor de la Restauración" como hacía el barón, sino a "un autor español". Por último, la definición del fandango como "baile puramente español, a tres tiempos y de aire vivo, etc." la toma directamente de Cotarelo y Mori (vid. COTARELO y MORI (1911): vol. I, CCXLIV).

100 REYES \& HERNÁNDEZ (2011). 
la carta de la que, sin embargo, ofrecen algunos párrafos por cierto, desordenados si se comparan con la carta original en latín- en traducción al castellano. Curiosamente, uno de ellos aparece dos veces traducido, con dos versiones diferentes. Nos referimos, en concreto, a la frase "Nec inter Aethiopas tantum et obscuros homines...", que primero se vierte de este modo: "No es festejada solo por gitanas u otras personas de baja condición..."; y pocas líneas después, de este otro: "No solamente le honran las negras y las personas de baja condición..."101. En nota al pie, reseñan el texto de Aurelio Capmany; no queda claro, sin embargo, si han tenido o no ocasión de consultarlo directamente o si, por el contrario, lo citan a partir de un artículo de Antonia A. Bustos Rodríguez.

Esta autora incluye en su trabajo un fragmento más amplio de la carta ${ }^{102}$. Lo sorprendente es que, aunque en nota al pie cita tan sólo a Capmany, se permite "retocar" la traducción que éste ofrece y además complementarla con otra que toma de José Luis Navarro, o bien de Ruiz Campos, a ambos sin citarlos. Es más, atribuye equivocadamente otro párrafo de la carta de Martí al padre Juan de Mariana, confundiendo el apellido del diligente jesuita con el de nuestro deán.

Continuando con nuestro viaje al revés, toca ahora el turno a José Luis Navarro. En su interesantísima obra sobre los orígenes del baile flamenco, dedica, como es lógico, un capítulo al fandango ${ }^{103}$. En él menciona la carta del deán, identificándola como uno de los primeros testimonios que tenemos de cómo se bailaba el fandango en Cádiz. Por cierto que fecha la carta un 16.02.1712, seguramente por un error de interpretación del calendario romano ${ }^{104}$. Navarro reproduce traducido un fragmento de la carta, precisamente el más escabroso de la misma, aquel que, recordamos, optó por suprimir Davillier y, por consiguiente, Capmany. Ésta es la versión que ofrece:

Los cuerpos se mueven al son de las cadencias de la música, con todas las excitaciones de la pasión, con movimientos en extremo voluptuosos, taconeos, miradas, saltos, todas las figuras rebosantes de lascivas intenciones ${ }^{105}$.

Una traducción, a nuestro juicio, un tanto discutible y posiblemente mediatizada por la cercanía del autor al mun-

101 REYES \& HERNÁNDEZ (2011): 41-42. Cf. nota 16. 102 BUSTOS (2009): 36-47.

103 NAVARRO (2008): vol. I, 113 y ss.

104 Ya vimos antes que Davillier fecha la carta el 16 de las $c a$ lendas de febrero. Por su parte, el Diccionario Enciclopédico Ilustrado del Flamenco de BLAS \& RÍOS (1988) da como fecha el 17.03.1712. Cf. nota 27.

105 NAVARRO (2008): 115. do y estudio del flamenco. No creemos, en todo caso, que traducir "clunium motationes" o "micationes femorum" por "taconeos" sea la opción más fidedigna, pues ambos sintagmas apuntan claramente al trémulo movimiento de nalgas y muslos de los danzantes.

De todos modos, esta traducción parece deberse a Ruiz Campos, autor de un capítulo sobre el fandango incluido en la Historia del flamenco de la editorial Tartessos (de cuya dirección se encargó el propio José Luis Navarro junto a Miguel Ropero Núñez), donde recoge un amplio fragmento de la carta de Martí traducido al español ${ }^{106}$. En nota al pie advierte Ruiz Campos que la carta original del deán la toma de J. F. Peyron, como ya sabemos, el primero en citarla y vincularla con el fandango.

Un poco antes que Navarro, Hernández Jaramillo ya había recogido un fragmento de la carta de Martí en una traducción o, mejor, recreación en castellano un tanto peculiar $^{107}$. Como muestra de lo que decimos, ponemos un ejemplo; la frase original: "Saltant vir et femina, vel bini, vel plures" se vierte al castellano de este modo: "El fandango lo baila a veces un hombre solo, a veces una mujer sola", como si el deán nombrara en algún momento el fandango o hubiera dicho que podía bailarse en solitario.

Aunque no cita frase textual alguna, sorprendente es la noticia que sobre la carta nos transmite la última edición del New Grove. En el artículo "fandango", firmado por Israel J. Katz, se atribuye su autoría a un tal "Martín Martí", con el añadido de que la escribió un 17.03.1712 (la misma fecha que da el Diccionario Ilustrado del Flamenco de Blas Vega y Ríos Ruiz ${ }^{108}$. Realmente no es el único error, pues también adjudica a un tal "Francisco de Leefadeal" (sic.) la autoría del entremés anónimo El novio de la aldeana ${ }^{109}$, repetidamente citado desde Cotarelo y Mori como uno de los primeros ejemplos literarios en los que se menciona el baile del fandango ${ }^{110}$.

Gómez Rodríguez alude también en uno de sus trabajos a la carta de Martí, de la que recoge apenas un par de frases extraídas de la obra de Davillier en traducción al español ${ }^{111}$.

106 RUIZ (2002): 287-295.

107 HERNÁNDEZ (2002): 113.

108 KATZ (2001): vol. 8, 542-543.

109 Incluido en Arcadia de entremeses escritos por los ingenios más clásicos de España. Madrid, Imprenta de Ángel Pascual Rubio, 1723 ,pp. 87 y ss. NAVARRO (2008): 119, comenta que posiblemente la primera referencia aparezca en el entremés Alcalde nuevo, que él data, sin dar más referencias, en torno a 1680, aunque COTARELO (1911): CXXIII, lo hace en torno a 1719.

110 COTARELO (1911): CCXLV. 111 GÓMEZ (1998-1999): 149. 
Por su parte, Margarita Torrione, que defiende que una de las descripciones más plásticas y expresivas del fandango se debe a la pluma de Peyron, recuerda también la carta del deán, de la que extracta un fragmento que vierte en traducción propia al castellano. Como ya dijimos, nos parece interesante su acotación a propósito del gentilicio "etíope" sin embargo, consideramos en exceso libre e imaginativa la traducción del controvertido fragmento de la carta, aunque no negamos que capte su espíritu:

Hombres y mujeres danzan a dos o a varios. Al ritmo de la música los sentidos se excitan de muy diversos modos: brazos y piernas se mueven blandamente, las nalgas se menean, extravíanse las manos, la lubricidad se desencadena, se mima el asalto sexual, en fin, todos los pasos de la danza se orientan meticulosamente a provocar erección y lascivia. Se ve al hombre ondular las nalgas y a la mujer excitar a su compañero lanzando pequeños gemidos con una gracia y un encanto tales, que hasta las nalgas de Fotis, la amiga de Apuleyo, pareciera que habían de menearse sin gracia y con vulgaridad ${ }^{113}$.

En la entrada "fandango", el Diccionario Enciclopédico Ilustrado del Flamenco, data la carta dos meses más tarde que la fecha del original, citándose en traducción al castellano apenas una frase de la misma ("Ya conocéis esta danza de Cádiz, famosa desde hace tantos siglos"), con mucha probabilidad tomada de la obra de Davillier ${ }^{114}$.

Isabel Aretz también menciona al deán y su carta en uno de sus artículos ${ }^{115}$. Desvela que extrae la información, así como unas frases que cita, de Capmany; sorprendentemente, reproduce otro breve fragmento de la misma, desligándolo de Martí y datándolo en 1830.

Y ya para finalizar, Crivillé i Bargalló rememora también la carta del deán, de la que extracta un corto pasaje que, si hacemos caso a la referencia a pie de página, toma de Capmany ${ }^{116}$.

Llegados a este punto, estaríamos ya en condiciones de responder a la pregunta que nos formulábamos al comienzo de este trabajo. No hay duda de que los responsables de que la carta de Martí se haya asociado hasta el presente con el baile del fandango han sido los autores de libros de viaje por España, principalmente los franceses y, muy en especial, uno

$112 C f$. nota 16 .

113 TORRIONE (1992): 13.

114 BLAS \& RÍOS (1988): vol. I, 284. Unos años antes, RÍOS RUIZ recogía ya esta información en su Introducción al cante flamenco (RÍOS (1972): 86).

115 ARETZ (1984-1985): 117-131.

116 CRIVILLÉ (1983): 222. de ellos, Jean-François Peyron, el primero en citarla. El efecto que produjo Peryon al hacerlo fue muy similar a las ondas provocadas por una piedra lanzada en un estanque; una vez identificada la descripción de Martí con el baile del fandango y otorgándosele a nuestro deán la categoría de auctoritas, la onda comenzó a expandirse, y así ha seguido hasta el presente. Al darse por hecho que el lascivo y desvergonzado baile que Martí presenció en Cádiz era un fandango, no tardó en alcanzar éste la escandalosa fama que, desde las postrimerías del siglo XVIII, lo ha acompañado. Y esto a pesar de que en las descripciones que leemos en Jean-François de Bourgoing, Alexandre Laborde o Étienne-François de Lantier no hallemos nada especialmente censurable; el fandango era un baile lascivo, Martí lo había certificado, y así debía seguir siendo. No es sólo que los viajeros, o pseudoviajeros, estuvieran contaminados por sus prejuicios hacia España; no, lo cierto es que también sus lectores esperarían encontrar en sus relatos ciertos tópicos sobre el peculiar carácter español y, qué duda cabe, la lasciva naturaleza del fandango era uno de ellos ${ }^{117}$. Amén de existir una cierta inclinación por caricaturizar o resaltar ciertos aspectos negativos o escandalosos de los españoles ${ }^{118}$, el fandango epitomizaba, en este sentido, el sentimiento negativo que los extranjeros tenían sobre los españoles ${ }^{119}$. Y no hay que olvidar que, tal y como hemos podido comprobar a lo largo de estas líneas, muchos de los autores de este tipo de libros acostumbraban a alimentarse unos de otros, haciendo gala de un saber erudito y libresco que, en ocasiones, pretendía ocultar su escaso o nulo contacto con la realidad. Pero, ¿y si el fandango no hubiera sido tan licencioso, como se supone, en su origen?

Hay un dato que nos llama poderosamente la atención, y es la definición que de él da el Diccionario de Autoridades ${ }^{120}$, donde en modo alguno se alude al pretendido carácter lascivo de este baile. Dice así la entrada:

FANDANGO. S. m. Baile introducido por los que han estado en los Reinos de las Indias, que se hace al son de un tañido muy alegre y festivo. banda $^{121}$.

En cambio, sí que lo certifica a propósito de la zara-

117 Vid. TORRIONE (1992): 10.

118 Vid. TAMARIT (2003): 17 y ss.

119 Vid.ETZION (1993): 29.

120 Aparece en el tercer volumen (letras de la D a la F), que se publicó en 1732 , por tanto, en una fecha muy cercana a la redacción de la carta de Martí.

$121 \mathrm{La}$ referencia aparece en el sexto volumen (letras S a la Z), publicado en 1739 . 
ZARABANDA. S. f. Tañido, y danza viva y alegre, que se hace con repetidos movimientos del cuerpo poco modestos.

Es cierto que la expresión latina equivalente, tripudium fescenninum, que sugiere para "fandango" invitaría a pensar en una danza de carácter, cuando menos, satírico; pero no tanto, de cualquier modo, como la que propone para "zarabanda", que directamente califica de danza desvergonzada, petulans saltatio.

Entonces, lo que vio bailar Martí en Cádiz ¿fue o no realmente un fandango? Y en caso de que lo fuera, ¿sabría el deán que se trataba de dicho baile? En relación a la primera cuestión, no nos atreveríamos a dar una respuesta segura. Tanto por su descripción del baile -mediatizada, no obstante, por la certeza de encontrarse ante un vestigio de la Antigüedad Clásica, una evolución del famoso baile de las puellae gaditanae - como por su alusión a los "etíopes", nos inclinaríamos a pensar que se trataría de uno de los bailes de origen negro que desde el siglo XV entraron en la Penínsu$1 \mathrm{a}^{122}$; bailes entre los que se encuentran la zarabanda, la chacona o el zarambeque ${ }^{123}$. Y también el fandango que algunos autores, probablemente recordando la descripción de Martí, han querido emparentar con la chica o con la calenda.

En cuanto a la segunda cuestión, nos inclinamos a pensar que no. Y es que el deán no puntualiza en momento alguno de qué baile en concreto se trata. De haberlo sabido, creemos, lo hubiera indicado; de un modo tan sencillo como éste: "Nosti saltationem illam Gaditanam (vulgo dicitur fandango)...". Pero no lo hace; y ocasión no le faltaría, si no en el momento justo de redactar la carta, sí más tarde cuando, presumiblemente, hubo de revisarla cara a su publicación. Es más, ¿qué interés podría tener darla a la luz? Es lógico pensar que Mayans, siguiendo los consejos del propio Martí, seleccionara las cartas que merecieran tal honor. ¿Y a cuento de qué publicar precisamente esta carta, dirigida además a un señor cuya relación con Martí no terminó nada bien? La respuesta es obvia: porque ambos debieron considerarla una aportación más al conocimiento de la Antigüedad Clásica; porque, en definitiva, a ojos del deán lo que vio bailar en Cádiz no fue otra cosa que una versión actualizada de la famosa danza de las puellae gaditanae, un vestigio todavía vivo de esa sensual y provocativa danza que, entre otros, tan bien inmortalizó la afilada y certera lengua de Marcial.

122 Vid. NAVARRO (2008): 59 y ss.

123 Dice del zarambeque el Diccionario de Autoridades (letras de la S a la Z, 1739): "Tañido, y danza muy alegre, y bulliciosa, la cual es muy frecuente entre los negros. Lat. Aetiopum festiva saltatio".

\section{Bibliografía}

Arago, Promenade autour du monde. Paris, Leblanc, 1822, vol. I, 222.

Arcadia de entremeses escritos por los ingenios más clásicos de España. Madrid, Imprenta de Ángel Pascual Rubio, 1723, 87 y ss.

Aretz, Isabel, "La música ibérica en América", Anuario Musical, 39/40 (1984-1985), 117-131.

Asenjo Barbieri, Francisco, Las castañuelas: estudio jocoso. Madrid, Aribau, 1878.

Baron, Auguste A. Floreal, Entretiens sur la danse ancienne, moderne, religieuse, civile et théatrale, accompagnés d'une lithographie chorégraphique. Paris, DondeyDuprè, 1824.

Baron, Auguste A. Floreal, Lettres à Sophie sur la danse. Paris, Dondey-Dupré, 1825.

Blas Vega, José y Ríos Ruiz, Manuel, Diccionario Enciclopédico Ilustrado del Flamenco. Madrid, Cinterco, 1988.

Blasis, C., The code of Terpsichore. London, Edward Bull, 1830a.

Blasis, C., Manuel complet de la danse (Barton, M. y Vergnaud, M. Paul, trad. de l'anglais). Paris, Librairie Encyclopédique de Roret, 1830b.

Bourgoing, Jean-François de, Nouveau voyage en Espagne ou tableau de l'état actuel de cette monarchie. Paris, Regnault, 1789.

Bustos Rodríguez, Antonia Aux., "Divertimentos en el siglo de oro español", Danzaratte: Revista del Conservatorio Superior de Danza de Málaga, 6 (2009), 36-47.

Camós Cabeceran, Agustí, “Antoni Bergnes de las Casas (1801-1879), difusor de la cultura científica y del transformismo lamarckista", Llull, Revista de la Sociedad Española de Historia de las Ciencias y de las Técnicas, 21/42 (1998), 633-651.

Capmany, Aurelio, "El baile y la danza", en Carreras y Candi, Francisco (dir.): Folklores y costumbres de España. 3 vols. Madrid, Ediciones Merino, 1988, 247-251 [1 $1^{\mathrm{a}}$ ed., Barcelona, Alberto Martín, 1931-1933].

Cotarelo y Mori, Emilio, Colección de Entremeses, loas, bailes, jácaras y mojigangas. Madrid, Bailly// Bailliére, 1911.

Crivillé i Bargalló, Josep, Historia de la música española 7. El folklore musical. Madrid, Alianza Música, 1983.

Daremberg \& Saglio, Dictionnaire des antiquités grecques et romaines. Graz, Akademische Drunch, 1962.

Davillier, Ch., "Voyage en Espagne par MM. Gustave Doré et Ch. Davillier", Le Tour du Monde. Nouveau Journal des 
Voyages. (Charton, Édouard, dir.). Deuxième Semestre. Paris, Librairie de L. Hachette, 1866, 388-416.

Davillier, Ch., Voyage en Espagne par Gustave Doré et le Baron Ch. Davillier, Le Tour du Monde, 1862-1873. Valencia, Gráficas Soler, 1974.

Delaporte, Le voyageur français ou la connaissance de l'ancien et du nouveau monde. Paris, L. Cellot, 1772.

Díaz, Gonzalo, Hombres y Documentos de la Filosofía Española. Madrid, CSIC, 1995.

Don Preciso, Colección de las mejores coplas de seguidillas, tiranas y polos que se han compuesto para cantar a la guitarra. 2 vols. Madrid, 1799.

Etzion, Judith, "The Spanish Fandango. From EighteenthCentury "lasciviousness" to Nineteenth-Century exoticism", Anuario Musical, 48 (1993), 229-250.

Fernández Herr, Elena, Les origines de l'Espagne romantique: les récits de voyage: 1755-1823. Paris, Didier, D. L., 1974.

Fertiault, Histoire anecdotique et pittoresque de la danse chez les peuples anciens et modernes. Paris, Auguste Aubry, 1854, 93 y 126-127.

Fleuriot, Jean-Marie-Jerôme, Voyage en Espagne, par Langle. Paris, J. J. Lucet, 1796 [1 ${ }^{\text {a }}$ ed., Saint-Malo, 1784].

Gil, Luis, Vida del deán de Alicante, traducción, estudio preliminar y comentario. Valencia, Publicaciones del Ayuntamiento de Oliva, 1977, 159. Disponible en Biblioteca Valenciana Digital, http://bivaldi.gva.es/es/ corpus/unidad. $\mathrm{cmd}$ ?idCorpus $=20000 \&$ idUnidad $=476$ 97\&posicion=1 (consultado el 12-09-2011).

Gil, Luis, "Los Apuntes autobiográficos del deán Martî”, Boletín de la Real Academia Española, 58 (1978), 47-101.

Gil, Luis, "Opúsculos del deán Martí: Apuntes autobiográficos", en GIL, Luis: Estudios de humanismo y tradición clásica. Madrid, Editorial de la Universidad Complutense, 1984. 265-314.

Gil, Luis, "Entre clérigos anda el juego. La versión griega de los Martialis disticha del deán Martí y el Lusus convivialis de Interián de Ayala", Cuadernos de Filología Clásica. Nueva Serie I. Madrid, Facultad de Filología, Universidad Complutense de Madrid, 1991, 29-42.

Gómez Rodríguez, José Antonio: "De etnomusicología española: notas de una historia. Una aproximación al folklore musical del XVIII a través de la literatura", Cuadernos de estudios del siglo XVIII, 9 (1998-1999), 127-168.

Guenebault, Natural History of the Negro Race, extracted from the French. Charleston, D. J. Dowling, 1837.

Hernández Jaramillo, José Miguel, La música preflamenca. Sevilla, Consejería de Relaciones Institucionales de la Junta de Andalucía, 2002.
Iriarte, Tomás de, La música. Poema. Madrid, Imprenta Real de la Gazeta, 1779.

Jahn, Janheinz: Muntu: las culturas de la negritud (Romero, Daniel, trad.). Madrid, Ediciones Guadarrama, 1970.

Jeschke, Vettermann, \& Haitzinger, Les choses espagnoles: Research into the panomania of 19th century dance. München, Epodium, 2009.

Katz, Israel, "Fandango", The New Grove Dictionary of Music and Musicians. New York, Oxford University Press, 2001, vol. 8, pp. 542-543.

Labat, Jean-Baptiste, Nouveau Voyage aux isles Françoises de l'Amérique. Paris, Giffart, 1722.

Labat, Jean-Baptiste, Voyage en Espagne et en Italie. Amsterdam, 1731.

Laborde, Alexandre de, Itinéraire déscriptif de l'Espagne et tableau élémentaire des differents branches de l'administratioin de ce royaume. París, $\mathrm{H}$. Nicolle, 1808-1809.

Lantier, Étienne-François de, Voyage en Espagne du Chevalier Saint-Gervais, officier français, et les divers événements de son voyage. Paris, Arthus-Bertrand, 1809.

Le Conseiller des dames et demoiselle: journal d'économie domestique et de travaux a l'aiguille. Paris, Penaud Frères, 1852-1853.

Loménie, Louis de, Beaumarchais et son temps. Paris, Michel Lévy Frères, 1856.

Mariana, Juan de, "Tratado contra los juegos públicos", $B i$ blioteca de Autores Españoles: Obras del padre Juan de Mariana, vol. II. Madrid: Rivadeneyra, 1854, [1609].

Marino, Giambattista, Opere del Cavalier Giambattista Marino... con un discorso preliminare di Giuseppe Zirardini. Napoli, C. Boutteaux, E. M. Aubry, Editori, 1861.

Martí, Manuel, "Carta de Martí a Mayans, de 30.08.1721" (Mestre, Antonio, ed.), en Biblioteca Digital Valenciana (consultada el 05.10.2011). http://bv2.gva.es/es/ corpus/unidad.cmd?idCorpus $=20 \quad$ 000\&idUnidad $=$ 48616\&posicion $=1]$.

Martí, Manuel, Emmanuelis Martini Ecclesiae Alonensis Decani Epistolarum Libri Duodecim. Mantuae Carpetanorum, apud Joannem Stunicam, Anno MDCCXXXV, 1735. Edición digitalizada del vol. 2, http://books.google.es/books?id= S0y9YfpiAIMC\&printsec $=$ frontco ver\&hl=es\&source $=$ gbs_ge_summary_r\&cad $=0 \# \mathrm{v}=0$ nepage \&q\&f=false (consultado el 12.09.2011).

Martí, Manuel, Emmanuelis Martini Ecclesiae Alonensis Decani Epistolarum Libri Duodecim. Accedunt auctoris nondum defuncti Vita, a Gregorio Majansio conscripta, nec non praefatio Petri Wesselingii. Amstelaedami, apud J. Wetstenium \& G. Smith, MDCCXXXVIII, 1738. 
Martí, Manuel, Pro crepitu ventris. Roque Valero traduc. Oración que en defensa del pedo compuso el doctísimo y célebre don Manuel Martí. Sevilla, Imprenta de Vázquez, Hidalgo y Compañía, s.f. [finales del siglo XVIII]).

Mayans, Gregorio, Emmanuelis Martini, Ecclesiae Alonensis Decani, Vita. Madrid, Joannis Stunica, 1735. Edición digitalizada en http://bv2.gva.es/es/consulta/busqueda_referencia.cmd?campo $=$ idtitulo\&idValor $=3708$ (consultado el 10-09-2011).

Mayans, Gregorio, "Carta de Don Gregorio Mayans i Sicar a don Francisco de Almeida...dándole noticia de la muerte de Don Manuel Martí, Dean de Alicante", Cartas morales, militares, civiles i literarias de varios autores españoles, recogidas y publicadas por don Gregorio Mayans i Sicar. Valencia, Salvador Faulí, 1773, vol. II, 382-397.

Mestre, Antonio, "El deán de Alicante: entre la ilusión y la desesperanza", Humanismo y crítica histórica en los ilustrados alicantinos. Alicante, Universidad de Alicante, 1980, 14-57.

Mestre, Antonio, "La carta, fuente de conocimiento histórico", Revista de Historia Moderna, Anales de la Universidad de Alicante, 18 (2000), 13-26.

Mestre, Antonio, Manuel Martí, el Deán de Alicante. Alicante, Instituto Alicantino de Cultura Juan Gil Albert, 2003.

Mestre, Antonio, Los ilustrados, el origen de la imprenta y el catálogo de incunables españoles. Valencia, Generalitat Valenciana, 2007.

Moreau de Saint-Méry: Description topographique, physique, civile, politique et historique de la partie française de l'île Saint-Domingue. Philadelphie, 1797.

Navarro García, José Luis, Historia del baile flamenco. Sevilla, Signatura Ediciones, 2008.

Ortas Durand, Esther, "La España de los viajeros (17551846): imágenes reales, literaturizadas, soñadas", Los libros de viaje: realidad vivida y género literario. (Romero Tobar, Leonardo y Amarcegui Elduayen, Patricia, coords.). Madrid, Akal, 2005, 48-91.

Panckoucke, Charles Louis Fleury (ed.), Dictionaire de sciences médicales, 60 vols., 1812-1822.

Pellicer, Casiano, Tratado histórico sobre el origen y progresos de la comedia y del histrionismo en España. Madrid, Imprenta de la Administración del Real Arbitrio de Beneficiencia, 1804.

Peyron, Jean-Baptiste, Essais sur l'Espagne. Voyage fait en 1777 et 1778, où l'on traite des moeurs, du caractère, des monuments, du commerce, du théâtre, et des tribunaux particuliers à ce royaume. Ginebra, 1780.

Plaza Orellana, Rocío, El flamenco y los románticos: un viaje entre el mito y la realidad. Sevilla, Bienal de Arte Flamenco, 1999.

Reyes Zúñiga, Lénica y Hernández Jaramillo, José Miguel, "Cádiz como eje vertebrador en España del discurso dialógico musical entre México y Andalucía en la etapa preflamenca", Revista del Centro de Investigación Flamenco Telethusa, $\mathrm{n}^{\circ} 4$, vol. 4 (2011). http://www.flamencoinvestigacion.es/0404-2011/revista-cift.pdf.

Ríos Ruiz, Manuel, Introducción al cante flamenco. Madrid, Istmo, 1972.

Ruiz Campos, Alberto Manuel, "El fandango", Historia del Flamenco. (Navarro García, José Luis y Ropero Núñez, Miguel, dirs.). Sevilla, Tartessos, 2002, vol. I, 287-295.

Sarrailh, Jean, "Voyageurs français au XVIIIe siècle. De l'abbé de Vayrac à l'abbé Delaporte", Bulletin Hispanique, 36/1 (1934), 29-70.

Swinburne, Henry, Travels through Spain in the years 1775 and 1776. Londres, Elmsly, 1787.

Tamarit Vallés, Inmaculada, Representaciones de la mujer española en el imaginario francés del siglo XVIII. Tesis doctoral, Valencia, Universidad de Valencia, Servicio de Publicaciones, 2003.

Torrione, Margarita, "Del viajero ilustrado al viajero romántico. Visión del folclore gitano-andaluz", "Los intelectuales ante el flamenco". Cuadernos Hispanoamericanos. Los Complementarios 9-10, Mayo 1992. (Caballero, A. Ángel, et alii). Madrid, Gráficas 82, 9-30.

Twiss, Richard, Travels through Portugal and Spain in 1772 and 1773. Londres, 1775.

Virey, Julien-Joseph, Histoire naturelle du genre humain. Paris, Dufart, 1801.

Virey, Julien-Joseph, De la femme, sous ses rapports physiologique, moral et littéraire (seconde édition). Paris, Crochard, 1825.

Virey, Julien-Joseph, Historia natural del jénero humano, puesta en castellano por D. Antonio Bergnes de las Casas ( $3^{\mathrm{a}}$ ed.). Barcelona: Juan Olivares, 1846.

Ximeno, Vicente, Escritores del Reyno de Valencia. Valencia, Joseph Estevan Dolz, 1774. 